\title{
Cardiomyocyte Dysfunction in Inherited Cardiomyopathies
}

\author{
Roua Hassoun ${ }^{1,2}$, Heidi Budde ${ }^{1,2}$, Andreas Mügge ${ }^{1,2}$ and Nazha Hamdani 1,2,* \\ 1 Institut für Forschung und Lehre (IFL), Molecular and Experimental Cardiology, Ruhr University Bochum, \\ 44801 Bochum, Germany; Roua.Hassoun@rub.de (R.H.); heidi.budde@rub.de (H.B.); \\ andreas.muegge@ruhr-uni-bochum.de (A.M.) \\ 2 Department of Cardiology, St. Josef-Hospital and Bergmannsheil, Ruhr University Bochum, \\ 44801 Bochum, Germany \\ * Correspondence: nazha.hamdani@rub.de; Tel.: +49-(0)234-50959053; Fax: +49-(0)234-3214904
}

Citation: Hassoun, R.; Budde, H.;

Mügge, A.; Hamdani, N.

Cardiomyocyte Dysfunction in Inherited Cardiomyopathies. Int. J. Mol. Sci. 2021, 22, 11154. https:// doi.org/10.3390/ijms222011154

Academic Editor: Michael T. Chin

Received: 24 September 2021

Accepted: 13 October 2021

Published: 15 October 2021

Publisher's Note: MDPI stays neutral with regard to jurisdictional claims in published maps and institutional affiliations.

Copyright: (C) 2021 by the authors. Licensee MDPI, Basel, Switzerland. This article is an open access article distributed under the terms and conditions of the Creative Commons Attribution (CC BY) license (https:/ / creativecommons.org/licenses/by/ $4.0 /)$.

\begin{abstract}
Inherited cardiomyopathies form a heterogenous group of disorders that affect the structure and function of the heart. Defects in the genes encoding sarcomeric proteins are associated with various perturbations that induce contractile dysfunction and promote disease development. In this review we aimed to outline the functional consequences of the major inherited cardiomyopathies in terms of myocardial contraction and kinetics, and to highlight the structural and functional alterations in some sarcomeric variants that have been demonstrated to be involved in the pathogenesis of the inherited cardiomyopathies. A particular focus was made on mutation-induced alterations in cardiomyocyte mechanics. Since no disease-specific treatments for familial cardiomyopathies exist, several novel agents have been developed to modulate sarcomere contractility. Understanding the molecular basis of the disease opens new avenues for the development of new therapies. Furthermore, the earlier the awareness of the genetic defect, the better the clinical prognostication would be for patients and the better the prevention of development of the disease.
\end{abstract}

Keywords: inherited cardiomyopathies; sarcomeric proteins; mutations; cardiomyocyte mechanics

\section{Introduction}

Genetically inherited cardiomyopathies form a heterogeneous group of cardiac disorders characterized by structural and/or functional disturbances in the myocardium. Inherited cardiomyopathies have been described as a known cause of heart failure, arrythmia, and sudden cardiac death [1-3]. The phenotypic manifestation and severity of clinical outcomes can vary considerably among affected individuals. As defined by Elliot et al., 2008, cardiomyopathies are classified according to functional and morphological features into four major types: hypertrophic cardiomyopathy (HCM), dilated cardiomyopathy (DCM), restrictive cardiomyopathy (RCM), and arrhythmogenic cardiomyopathy (ACM) (Figure 1). These classes are further divided into genetic/familial and non-genetic/nonfamilial forms [4]. Over the past two decades, numerous mutations in sarcomeric proteins have been well established as the cause of different types of inherited cardiomyopathies (Figure 2), however, the molecular mechanisms underlying the transition from the mutation to the cardiac phenotype is not fully understood.

In this review we aimed to outline the functional consequences of the major inherited cardiomyopathies in terms of myocardial contraction and kinetics, and to highlight the structural and functional alterations in some sarcomeric variants that have been demonstrated to be involved in the pathogenesis of the inherited cardiomyopathies. 


\section{Cardiomyopathies}

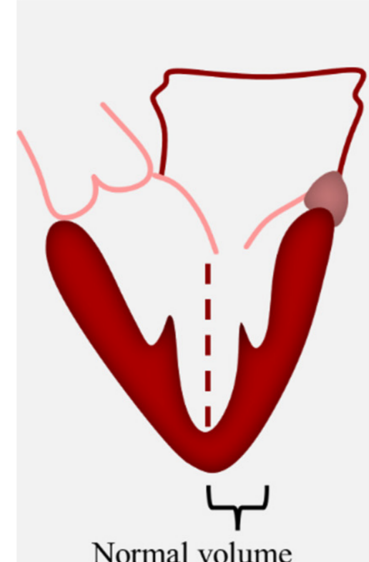

Normal

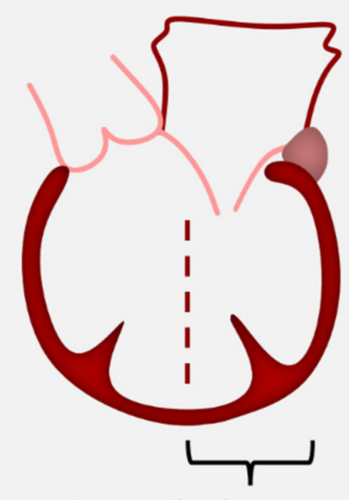

Increased volume

DCM

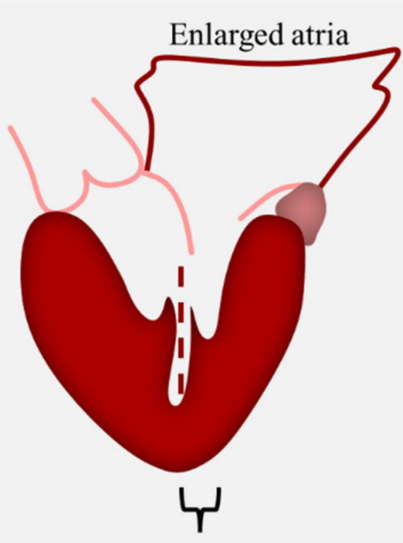

Reduced volume

HCM

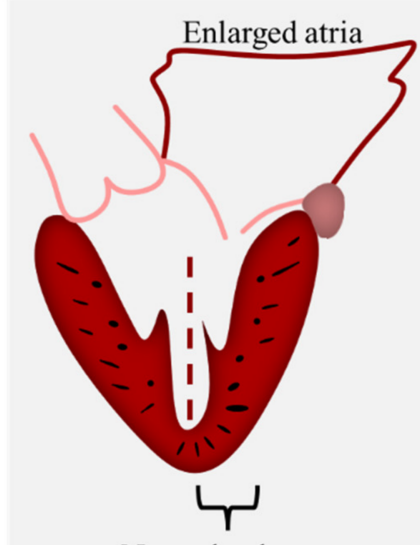

Normal volume

RCM

Figure 1. Scheme demonstrating the morphological features of HCM, DCM, and RCM.

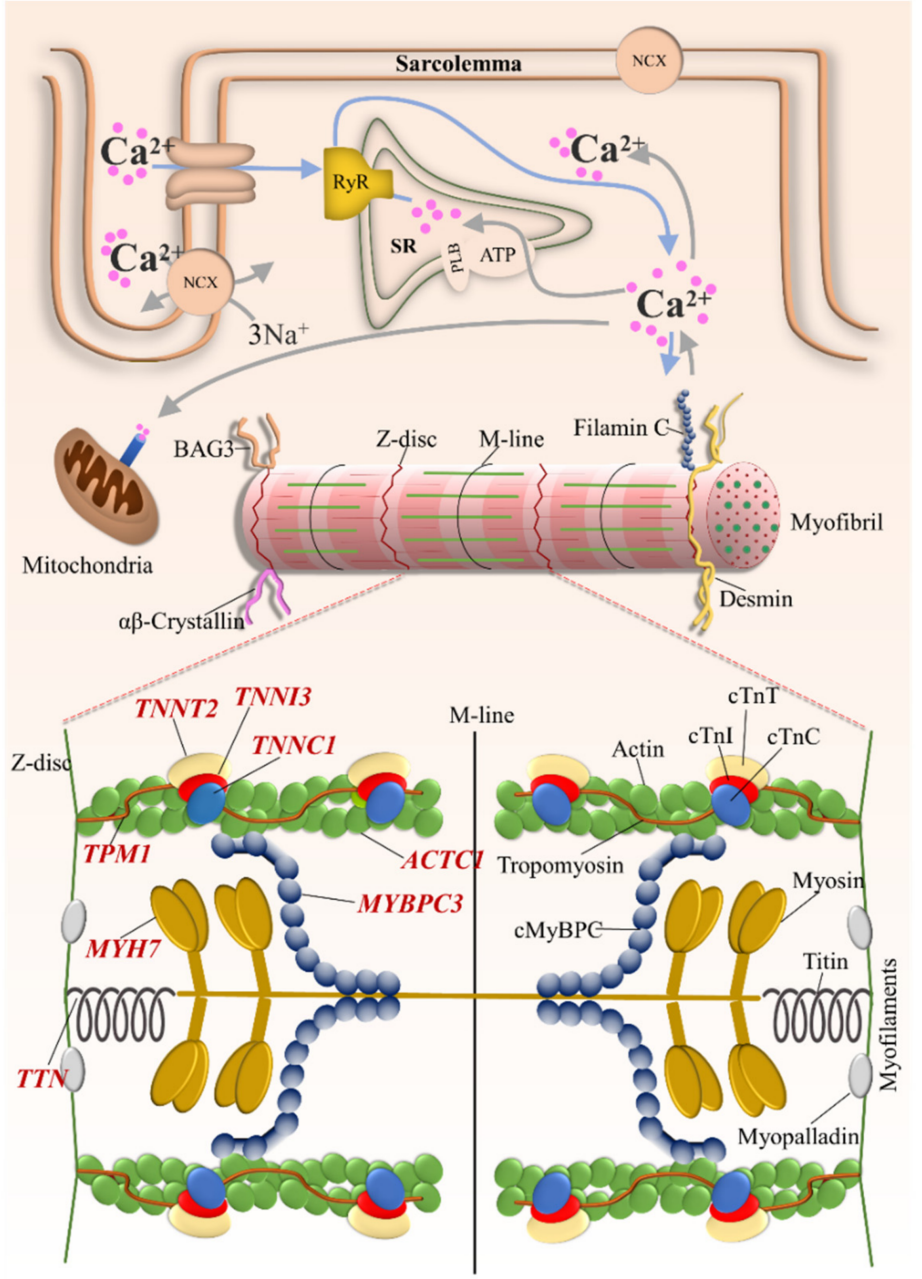

Figure 2. Schematic representation of the cardiomyocyte demonstrating sarcomeric genes with subcellular localization of the encoded protein. TNNT2 = cardiac troponin T2; TNNI3 = cardiac troponin I; TNNC1 = cardiac troponin C; TPM1 $=\alpha$-tropomyosin; TTN $=$ titin; $A C T C 1=\alpha$-cardiac actin; $M Y H 7=\beta$-myosin heavy chain; $M Y B P C 3=$ cardiac myosin binding protein $C$. 


\section{Classification}

A complete classification of cardiomyopathies is divided into primary and secondary. Primary cardiomyopathies which affect the heart alone, and secondary which are the results of systematic illness affecting many parts of the body [5].

In this review, we focused mainly on the pathogenic and likely pathogenic variants that are associated with the development of inherited cardiomyopathies.

Clinvar clinical significance of the genetic variants of sarcomeric proteins follows the five terms for Mendelian diseases recommended by the American College of Medical Genetics and Genomics (ACMG) [6], in which the genetic variants are classified into five categories: "pathogenic", "likely pathogenic", "uncertain significance", "likely benign", and "benign". This classification is based on criteria that include typical types of variant evidence such as population data, computational data, functional data, and segregation data [7]. Furthermore, the impact of the genetic variant depends on evolutionary conservation of an amino acid, the location within the protein, and the biochemical consequence of the amino acid substitution [7]. A genetic variant is considered pathogenic when the sequence variation is previously reported as disease-causing, whereas the likely pathogenic variants are those which are unreported but depending on the evolutionary conservation of the targeted amino acid, are predicted to cause the disease [6]. Variants with benign or likely benign classification are unreported to cause the disease and are expected to be non-pathogenic or probably non-pathogenic. The variant with uncertain significance refers to a variant that has an uncertain classification in the database.

\subsection{Hypertrophic Cardiomyopathy (HCM)}

$\mathrm{HCM}$ is a common autosomal dominant cardiac disorder with an estimated prevalence of 1:200 [1] and where more than $60 \%$ of patients show familial inheritance [8]. HCM is characterized by concentric wall thickening that mostly involve the interventricular septum and the left ventricle, causing a decrease in the chamber volume (Figure 1). The morphological features of HCM include myocyte hypertrophy, disarray, and fibrosis. Along with the reduced chamber volume, these hallmarks are known to cause diastolic dysfunction that manifest in heart failure and sudden cardiac death $[2,9,10]$ whereas, the left ventricular systolic dysfunction was shown to be relatively rare [11]. Molecular and genetic analysis revealed the involvement of more than 1400 sarcomeric protein mutations in HCM pathogenesis, hence HCM has been considered a disease of the sarcomere [12]. These mutations were identified in genes encoding for cardiac troponin, cardiac myosin binding protein $C$, cardiac myosin, cardiac actin, a-tropomyosin, and titin, however genes encoding for $\beta$-cardiac myosin heavy chain, cardiac myosin binding protein $C$, and cardiac troponins $\mathrm{T}$ and I are known to be the most frequent sites of HCM mutations [13].

\subsection{Dilated Cardiomyopathy (DCM)}

DCM is characterized by systolic dysfunction and ventricular dilation in one or both ventricles [14] with an estimated prevalence of 1:250-400 and up to 1:2500 in the general population [15] (Figure 1). The clinical presentation includes arrythmia and sudden cardiac death [3]. up to approximately $40 \%$ of DCM cases are caused by genetic mutations, whereas the non-genetic cases include drugs, toxins, alcohol, and viral or bacterial myocarditis [16]. Familial DCM exhibits several patterns of inheritance including autosomal dominant, X-linked, autosomal recessive and matrilinear transmission [3,17-19]. To date, more than 50 DCM mutations have been identified in genes encoding for cytoskeletal, sarcomere, nuclear envelope, and intracellular adhesion proteins $[15,20]$, in addition to other variants in ribonucleic acid-binding motif protein 20 (RBM20) and BAG3 genes [21,22]. The diversity of the affected pathways adds to the complexity of DCM pathogenesis and counts for the heterogeneity in phenotype expression. Sarcomeric DCM mutations include myosin, actin, titin, troponin, and tropomyosin [23]. 


\subsection{Restrictive Cardiomyopathy (RCM)}

$\mathrm{RCM}$ is the least common form of the cardiomyopathies. It is characterized by increased ventricular stiffness and severe diastolic dysfunction with normal wall thickness (Figure 1). The systolic function is preserved; however, it was found to be impaired at advanced stages of the disease [24]. The increase of ventricular end-diastolic pressures and atrial dilation are responsible for diastolic dysfunction and the subsequent development of progressive heart failure symptoms. Multiple inherited and acquired factors result in RCM phenotype, however, most causes of RCM are acquired. These include conditions that stiffen the myocardium such as infiltration, fibrosis, and storage diseases $[25,26]$. Since inherited RCM is a rare disease, the genetic and molecular understanding of its pathology is limited. Familial RCM is usually passed on in an autosomal dominant inheritance, other inheritance patterns, such as autosomal recessive and compound heterozygous, were also reported. It has been shown that the RCM phenotype can co-exist with HCM in the same families $[27,28]$. Furthermore, they can share some genetic mutations in sarcomeric proteins including troponin I (TNNI3), $\beta$-myosin heavy chain ( $M Y H 7)$, and myosin light chain-2 (MYL2) variants. Distinct sarcomeric and non-sarcomeric mutations were found to be associated with inherited RCM such as troponin T (TNNT2), alpha cardiac actin (ACTC), myosin-binding protein C (MYBPC3), tropomyosin 1 (TPM1), myosin light chain 2 (MYL2) and 3 (MYL3), $\alpha \beta$ crystallin, desmin, filamin C, and BAG3 [29].

\subsection{Arrhythmogenic Cardiomyopathy (ACM)}

ACM is a hereditary cardiac disorder with an estimated prevalence of 1:1000 to 1:5000 in the general population [30]. The main feature of ACM is the replacement of the ventricular myocardium with fibrofatty tissue, predominantly in the right ventricle but also the left ventricle can be affected [31]. It manifests clinically in a progressive disease with ventricular dilation, systolic dysfunction, and ventricular arrhythmia that can lead to sudden cardiac death [32]. ACM is a familial disease with an autosomal dominant mode of inheritance. Most of the causative mutations were found in desmosome genes (JUP, DSP, $P K P 2, D S G 2, D S C 2)$. Other genetic mutations include the composita area proteins, DES, $P L N, T G F B 3$, and SCN5A. Among the sarcomeric proteins, mutations in titin were found to cause ACM [32].

\section{Cardiomyopathy Causative Mutations in Sarcomeric Proteins}

\subsection{The Thick Filament}

\subsubsection{Myosin}

Myosin is a large ATPase consisting of two heavy chains and four light chains. Each heavy chain consists of a rod-like tail, extruding rod (sub-fragment S2) and a globular head (sub-fragment S1) with the light chains. The head possesses a catalytic center with ATPase activity and actin binding sites. Along the tail region, myosin binds titin and myosin binding protein $\mathrm{C}$ (MyBP-C). MyBP-C also binds to the S2 sub-fragment. In human cardiac muscle, two isoforms are expressed. $\beta-\mathrm{MyHC}$ is expressed predominantly in the ventricles and $\alpha$-MyHC in the atria. Along with MyBP-C mutations, mutations in $\beta$-MyHC gene $(M Y H 7)$ (recently reviewed in [33]) are a frequent cause of HCM [34]. Investigations on early-onset HCM mutations (D239N and H251N) reported the increase in myosin ATPase activity, actin gliding velocity and intrinsic force [35]. Studies on different HCM mutations using highly purified recombinant human $\beta$-cardiac myosin short Subfragment 1 (sS1), showed smaller changes in myosin biomechanical parameters, suggesting that these subtle alterations alone are unlikely to give rise to the HCM phenotype [36-38]. Another important effector through which hypercontractility can develop, is the altered intramolecular myosin interactions responsible for keeping myosin heads in a folded-back sequestered state [39]. Mutations that occur at the head-tail (R249Q, H251N) and head-head (D382Y, $\mathrm{R} 719 \mathrm{~W}$ ) interfaces have been suggested to disrupt intramolecular interactions within the sequestered state and cause more heads to become available for interaction with actin, thus leading to hypercontractility [40]. A recent study on the P710R mutation demonstrated 
that, even mutations that are not located in head-head or head-tail interface, might affect the ability of myosin to form the sequestered state via allosteric changes [41]. Furthermore, HCM mutations in myosin light chains have been associated with structural and functional defects in myosin [42]. In contrast to HCM mutations, DCM mutations diminish myosin activity. Biochemical characterization and mechanochemical cycle modelling of recombinant human $\beta$-cardiac myosin motor domains carrying five DCM mutations demonstrated that each mutation has a distinct effect on individual steps in the ATPase cycle depending on the location of each mutation. However, they show a common pattern on the overall cycle [43]. The DCM mutations lower occupancy of the force-holding A-M.D state (i.e., they accelerate myosin-actin detachment during cross-bridge cycle) $[43,44]$. The reduction in the number of myosin heads bound to actin leads to reduced work output and contractile function [45].

\subsubsection{Myosin Binding Protein $C$}

MyBPC is a key regulatory protein contributing to thick filament stability and the modulation of muscle contraction. There are three different isoforms, fast skeletal, slow skeletal and cardiac, encoded by three different genes. Each isoform comprises seven Ig and three fibronectin type III domains. The cardiac isoform (cMyBPC), encoded by $M Y B P C 3$ gene, has some specific additions. The $\mathrm{N}$-terminal $\mathrm{C} 0$ domain, the conserved linker between $\mathrm{C} 1$ and $\mathrm{C} 2$, and a 28 -amino acid loop in the $\mathrm{C} 5$ domain. Through its Nterminal domain, cMyBPC binds to the helical myosin $\mathrm{S} 2$ region, the actin filament and troponin complex [46]. The C-terminal region of cMyBPC binds the backbone region of myosin and titin. cMyBPC modulates the cardiac contractility in response to adrenergic stimulation and its subsequent phosphorylation by protein kinase A (PKA) [47,48]. In contrast to HCM, MYBPC3 mutations fond in DCM and RCM patients are rare $[29,49,50]$ (reviewed in [51,52]). The vast majority of HCM-linked mutations in $M Y B P C 3$ are truncating mutations [34] including frameshift, nonsense, or conserved RNA splice site mutations. cMyBPC-truncated variants were strongly associated to allelic imbalance and haploinsufficiency leading to HCM phenotype [52]. Although HCM-linked missense (non-truncating) mutations in $M Y B P C 3$ are associated with more benign outcomes, functional and structural investigations of a subset of missense mutations reported disturbed cMyBPC architecture and protein-protein interactions [53] suggesting a protein poison peptide as a potential pathomechanism. However, recent have studies reported RNA splicing defects, resulting from premature stop codon, and protein destabilization cause protein haploinsufficiency in MYBPC3 missense mutations [54,55].

cMyBPC haploinsufficiency is strongly associated with enhanced $\mathrm{Ca}^{2+}$ sensitivity. The latter was attributed to hypophosphorylation of troponin I secondary to mutation-induced dysfunction [56]. Another mechanism through which haploinsufficiency contributes to contractile disfunction is the perturbed dynamic myosin conformations. Recent studies using mice models demonstrated that $\mathrm{CMyBPC}$ deficiency enhances the myosin state that enables ATP hydrolysis and thin filament interactions (DRX) and reduces the super relaxed conformation associated with low energy consumption (SRX) [54].

\subsection{Titin}

The giant protein titin, encoded by titin gene TTN, is a fundamental sarcomeric protein serving as a biological spring. Titin elasticity regulates the mechanical compliance of the heart through the modulation of passive tension, systolic and diastolic function, and length-dependent activation [57]. The titin molecule expands from the Z-disk (Nterminus) to the $\mathrm{M}$-band (C-terminus) region of the sarcomere and comprises four domains. The N-terminal domain anchors titin to the Z-disc. The I-band domain includes the highly elastic immunoglobulin-like (Ig) domains, PEVK region (rich in proline, glutamate, valine, and lysine), N2A, and/or N2B element providing titin its spring-like function. The rigid, inextensible A-band domain containing FNIII and Ig-domains, binds to the thick filament proteins. The C-terminal domain embeds titin to the M-band [58]. Cardiac muscle 
works under nonequilibrium conditions-it is stretched (and released) one or many times per second. Diastolic force development is not purely elastic but has long been known to include stretch velocity-sensitive components of viscous and/or viscoelastic nature, but both passive force and dynamic stiffness principally reflect the intrinsic viscoelastic properties of titin [58]. The elastic-force component of cardiac myofibrils can be described in terms of the entropic-spring properties of titin segments, but these do not explain passiveforce decay of cardiac myofibrils following quick stretch (stress relaxation), which is mainly determined by a slow viscoelastic component due to unfolding of the Ig domains and by a fast viscous drag due mainly to the interaction between titin and actin.

Missense point mutations in TTN are associated with different types of cardiomyopathies. RCM-causing mutation was found to be located at the highly conserved I/A junction, however the molecular mechanism of the disease progression remains elusive [59]. A few HCM associated mutations were identified, mostly at the Z-disc and I-band region, [60] and were shown to increase the binding affinity of $\alpha$-actinin to titin, thereby inducing maladaptive responses to the impaired force transmission during contraction. ACM-causing mutations in titin are distributed all over the molecule [61]. Taylor et. al., 2011 suggested that the initiation of the disease is promoted via titin proteolysis, as ACM titin mutations lower the structural stability of Ig domains and lead to titin degradation [61]. Titin missense variants were also found in some cases of DCM and were expected to contribute to the disease [62]. Most pathogenic TTN mutations are heterozygous truncating variants resulting from frameshift, nonsense, and essential splice site mutations predominantly within A-band titin (reviewed in [63]). Titin truncating variants count for $25 \%$ of familial DCM cases [63-65] and are shown to be present in approximately $2 \%$ of the general population without distinct cardiomyopathy [66]. The effects of titin-truncated variants (TTNtv) are position dependent. In healthy carriers, the majority of TTNvs mutations were identified in the I-band exons. Mutations in the I-band exons are exposed to alternative splicing, whereas the A-band includes a vast array of constitutively expressed exons, hence, mutations at the I-band region are better tolerated [65].

TTNvs-based DCM is associated with a late onset, however, when combined with additional stressors and risk factors, they show earlier presentation. The mechanism by which TTNvs contributes to DCM is not fully understood, however, several mechanisms have been suggested to play an important role in DCM pathology. Haploinsufficiency was reported in animal model studies showing the increase of nonsense-mediated mRNA decay (NMD), titin insufficiency and a subsequent sarcomere disassembly $[67,68]$. Other studies suggested that the disease can be initiated via poison peptide mechanism rather than haploinsufficiency [65]. In patient-derived iPSC cardiomyocytes, TTN was found to be biallelically expressed [69]. Furthermore, and due to the loss of a $\beta$-cardiac myosin binding site on the mutated titin protein, abnormal sarcomerogenesis and impaired force generation were also detected in these cells [70]. Impaired signaling pathways and cardiac metabolism have been shown to be correlated with TTNvs-based DCM. Adams et al., 2019, reported the increase in ROS generation and mitochondrial dysfunction in rat hearts with TTNtv [71], in addition to the increase in the mammalian target of rapamycin (mTOR) phosphorylation and impaired autophagy.

\subsection{The Thin Filament}

\subsubsection{Actin}

Actins are highly conserved proteins among the species, they are classified into three groups of isoforms ( $\alpha$-actin, $\beta$-actin, and $\gamma$-actin) encoded by six different genes. $\alpha$-cardiac actin, encoded by ACTC1, is expressed predominantly in cardiac muscle. Under physiological conditions, the globular monomeric G-actin polymerizes to form a double helical filamentous structure (F-actin). The interaction of filamentous actin with $\beta$-myosin and other components of the contractile apparatus is essential for muscle contraction. Hence, cardiac actin mutations that alter this interaction are known to impair myocyte structure, cross-bridge cycling, and force generation. More than $50 \%$ of ACTC1 mutations are HCM- 
causing mutations and about $20 \%$ are DCM-causing mutations, however, they occur with an incidence of $4-6 \%$ in patients with familial cardiomyopathy. To date, twelve missense dominant mutations in ACTC1 have been reported to cause familial HCM (Table 1), and two to cause DCM [72]. Amino acid replacements that alter actin binding affinity towards myosin, such as E99K, were shown to affect acto-myosin interaction and force generation, leading to compensatory hypertrophy $[73,74]$. Other mutations were shown to affect actomyosin interaction indirectly, such as the A295S variant that has been associated with HCM. The position of amino acid substitution affects the tropomyosin-blocked-state binding side on actin resulting in altered thin-filament activation, increased $\mathrm{Ca}^{2+}$ sensitivity, and hypercontractility [75]. E361G, a DCM-causing mutation, was demonstrated to uncouple $\beta 1$-adrenergic signaling and affect $\mathrm{Ca}^{2+}$ sensitivity and troponin I phosphorylation [72]. Moreover, the DCM-causing R312H mutation was reported to affect actin-tropomyosin interaction and decrease the structural stability of thin filaments [76]. In a recent study by us, we found that both DCM-causing mutations (E361G and R312H) exhibited reduced rates of MICAL-induced depolymerization, indicating an increased persistence of these variants into sarcomeric structures which might potentially affect cardiomyocyte differentiation and function [77]. We have also shown that these variants incorporate differently into sarcomeric thin filaments which might lead to mechanical instability and sarcomere disturbances [77].

Table 1. Actin mutations associated with CMs.

\begin{tabular}{ccc}
\hline Variant & Phenotype & References \\
\hline R312H & DCM & {$[78]$} \\
E361G & DCM & {$[78]$} \\
E99K & HCM & {$[79]$} \\
P164A & HCM & {$[79]$} \\
A331P & HCM & {$[79]$} \\
Y166C & HCM & {$[80]$} \\
M305L & HCM & {$[80]$} \\
A295S & HCM & {$[81]$} \\
R314C & HCM & {$[82]$} \\
S271F & HCM & {$[83]$} \\
A232V & HCM & {$[84]$} \\
R97C & HCM & {$[85]$} \\
H90Y & HCM & {$[85]$} \\
F92del & HCM & {$[82]$} \\
\hline
\end{tabular}

\subsubsection{Tropomyosin}

Tropomyosin $(\mathrm{Tm})$ is an actin-binding regulatory protein. There are three groups of isoforms $(\alpha-\mathrm{Tm}, \beta-\mathrm{Tm}$, and $\gamma-\mathrm{Tm})$ encoded by different genes. $\alpha-\mathrm{Tm}$, encoded by TPM1, is the major isoform expressed in the heart. It consists of two parallel $\alpha$-helical coiled coils that span seven actin monomers forming a continuous homo or heterodimer [86]. Through its interaction with the heterotrimeric troponin complex, Tm plays an essential role in regulating the $\mathrm{Ca}^{2+}$-induced actin-myosin interaction [87-89]. Point-mutations in TPM1 have been discovered in patients with HCM and DCM (Table 2). Functional and structural analysis revealed altered interaction within Tm coiled coil and between Tm and actin [90]. The disturbed actin-Tm interaction affects the binding of the myosin head and results in altered cross-bridge kinetics [91]. Altered Tm-troponin interaction affects the three-state functioning of tropomyosin during thin filament activation [86,92]. Furthermore, mutation-induced-changes in tropomyosin flexibility were shown to modulate the $\mathrm{Ca}^{2+}$ dependent-activation cooperativity of the thin filament [93]. Redwood and Robinson 2013, suggested that the changes in $\mathrm{Ca}^{2+}$-regulation due to mutations, stimulate hypertrophic signaling pathways [94]. Memo et. al., 2013 reported that DCM mutations uncouple the effect of PKA-dependent troponin phosphorylation on $\mathrm{Ca}^{2+}$ sensitivity [95]. Hence, impaired myocardial contractility appears to be the primary effect of Tm mutations [94]. 
Table 2. Tropomyosin mutations associated with CMs.

\begin{tabular}{ccc}
\hline Variant & Phenotype & References \\
\hline E40K & DCM & {$[96]$} \\
E54K & DCM & {$[96]$} \\
D84N & DCM & {$[97]$} \\
D230N & DCM & {$[98]$} \\
M8R & DCM & {$[99]$} \\
K15N & DCM & {$[100]$} \\
E23Q & DCM IDC & {$[100]$} \\
I92T & DCM & {$[100]$} \\
T201M & DCM & {$[101]$} \\
A239T & DCM & {$[100]$} \\
A227V & DCM idiopathic & {$[100]$} \\
E192K & HCM sporadic & {$[102]$} \\
D58H & HCM & {$[103]$} \\
A107T & HCM & {$[104]$} \\
A22T & HCM & {$[104]$} \\
R21H & HCM & {$[105]$} \\
E62Q & HCM/RCM & {$[106,107]$} \\
A63V & HCM & {$[108]$} \\
K70T & HCM & {$[109]$} \\
V95A & HCM & {$[110]$} \\
I172T & HCM & {$[84]$} \\
M281T & HCM/RCM & {$[84,107]$} \\
L185R & HCM & {$[84]$} \\
D175N & HCM & {$[12]$} \\
E180G & HCM & {$[12]$} \\
E180V & HCM & {$[111]$} \\
S215L & Hove 40 years & {$[85]$} \\
I284V & HCM & \\
\hline & Hearly stageD & \\
\hline & HCM & \\
\hline
\end{tabular}

\subsubsection{Troponin Complex}

Cardiomyocyte contraction occurs as a result of cell membrane depolarization and subsequent elevation in cytosolic calcium level. The key role in the regulation of muscle contraction belongs to the troponin complex (Tn), discovered by Ebashi and Kodama, 1965 [112]. This protein consists of three subunits, troponin $\mathrm{T}$ (the Tpm-binding subunit, TnT), troponin I (the inhibitory subunit, TnI) which inhibits the ATPase activity of actomyosin complex in the absence of $\mathrm{Ca}^{2+}$, and troponin $\mathrm{C}$ (the $\mathrm{Ca}^{2+}$-binding subunit, $\operatorname{TnC})[86,113,114]$.

\section{Troponin C}

The cardiac/slow-twitch TnC ( $\mathrm{cTnC}$ ) isoform is encoded by TNNC1 gene, while TNNC2 encodes for fast skeletal isoform (fsTnC). cTnC is a member of the EF hand family of $\mathrm{Ca}^{2+}$-binding proteins. It has a dumbbell-shaped molecule that consists of two globular $\mathrm{N}$ - and C-terminal domains connected by a central helical linker. The two C-terminal high-affinity $\mathrm{Ca}^{2+}$-binding domains (EF3 and EF4) can bind either $\mathrm{Ca}^{2+}$ or $\mathrm{Mg}^{2+}$ which enhances the interaction of $\mathrm{cTnC}$ with $\mathrm{cTnI}$ and stabilizes the cTn complex. The N-terminal regulatory domain EF1 is a nonfunctional domain, while the domain EF2 has a low affinity but high selectivity for $\mathrm{Ca}^{2+}$, therefore, unlike the fast skeletal isoform of $\mathrm{TnC}$, which has four active $\mathrm{Ca}^{2+}$ binding sites, $\mathrm{cTnC}$ can only bind three $\mathrm{Ca}^{2+}$ ions [115]. Multiple mutations in TNNC1 have been associated with HCM, DCM and RCM [116] (recently reviewed in [117]), most of which were reported to modulate cTnC function by altering the $\mathrm{cTnC}$ binding affinity for calcium and/or its binding partners. Mutations in the Nterminal lobe are considered to affect the conformational activation (on and off states of cNTnC), $\mathrm{Ca}^{2+}$ binding properties and the binding-to-cTnI switch peptide [114,118]. L29Q is a well-studied HCM-causing mutation in cTnC. However functional studies using different 
experimental models reported contradictory results demonstrating $\mathrm{Ca}^{2+}$ sensitivity to be increased [119], decreased [120] or unchanged [121]. Other HCM mutations in cNTnC, such as $\mathrm{A} 8 \mathrm{~V}, \mathrm{~A} 31 \mathrm{~S}$ and $\mathrm{C} 84 \mathrm{Y}$ were strongly associated with increased $\mathrm{Ca}^{2+}$ sensitivity. These variants were shown to either increase the stability of cNTnC open conformation, thereby enhancing $\mathrm{Ca}^{2+}{ }^{2}$ binding affinity, or to directly increase the binding with $\mathrm{cTnI}$ [122-125]. In a recent study by us, we provided evidence on structural and functional alterations in thin filaments containing the novel cTnC G34S variant [126]. We found the TnC G34S mutation to increase $\mathrm{Ca}^{2+}$-binding affinity, decrease the binding affinity towards $\mathrm{CTnT}$, and to cause structural impairments in the reconstituted thin filaments. Mutations in the C-terminal lobe affect the interactions of cTnC with cTnI, cTnT, and Tpm [127]. The HCM-associated variant E145D was found to abolish $\mathrm{Ca}^{2+}$ binding to site IV and to increase $\mathrm{Ca}^{2+}$-binding to site II allosterically [128]. Furthermore, it has been demonstrated that the E145D variant alters interactions with the $\mathrm{N}$-terminal domain of $\mathrm{CTnI}(\mathrm{cNTnI})$ and the C-terminal domain of $\mathrm{cTnT}$ (cCTnT) [129]. HCM-associated mutations in $\mathrm{cTnC}$ have also been linked to the development of RCM phenotypes, such as A8V, A31S, and E145D variants [130,131].

The DCM-associated mutation G159D at the $\mathrm{CCTnC}$ was shown to impair the interaction with cTnT, decrease myofilament $\mathrm{Ca}^{2+}$ sensitivity, and blunt the effect of cTnI phosphorylation at Ser 22/23 [132,133]. In this case, the structural derangements caused by this mutation seems to exceed the TnI dephosphorylation which cannot compensate for the decrease in $\mathrm{Ca}^{2+}$ sensitivity [134]. The double compound heterozygous DCM variant (E59D/D75Y) has also been shown to decrease myofilament $\mathrm{Ca}^{2+}$ sensitivity and reduce strong actin-myosin binding $[135,136]$. A recent study by Landim-Vieira et al., 2019 on the missense compound heterozygous DCM-causing variants (D132N and D145E) demonstrated no significant changes in contractile parameters, indicating to the potential involvement of other pathological mechanisms beyond myofilament dysfunction [137].

\section{Troponin I}

Troponin I is the inhibitory subunit of troponin complex. Different genes encode the fast skeletal, slow skeletal and cardiac isoforms. CTnI, encoded by TNNI3, consists of several functional domains, a cardiac specific $\mathrm{N}$-terminal extension region (residues 1-32), an ITarm region, the inhibitory region (residues 130-150), the switch region (residues 151-167), and the C-terminal mobile domain. Protein kinase A (PKA)-mediated phosphorylation of cTnI at Ser-23/Ser-24 reduces myofilament $\mathrm{Ca}^{2+}$ sensitivity, increases the rate of $\mathrm{Ca}^{2+}$ dissociation from cTnC and cross-bridge cycling [138]. Mutations found in TNNI3 have been linked to DCM, RCM, and HCM (reviewed in [139]), most of which are located at the inhibitory region and C-terminal region of the protein. Families harboring D190G mutation exhibited mixed appearance of both RCM and HCM phenotypes, suggesting that some TNNI3 mutations might cause RCM and HCM in a similar mechanism [140]. Mutations within the inhibitory region of $\mathrm{CTnI}$ increase the binding affinity of cardiac troponin $\mathrm{C}$ in the absence of $\mathrm{Ca}^{2+}$, thereby increasing the basal level of ATPase activity and $\mathrm{Ca}^{2+}$ sensitivity which contributes to the depressed relaxation in HCM and RCM [141]. HCM mutations that were found at the C-terminal domain of $\mathrm{cTnI}$ exhibited decreased actin-myosin interaction, consequently reducing the inhibition of basal actomyosin ATPase activity and increasing the $\mathrm{Ca}^{2+}$ sensitivity of muscle contraction $[142,143]$. Furthermore, cCTnI mutations, such as R170W, showed disturbed incorporation into the thin filaments, which might potentially lead to excess protein accumulation and aggregation in the cytosol [29]. It has been also reported that HCM mutations, such as K206Q and R145G, uncouple the effect of TnI phosphorylation by PKA [144]. Furthermore, we showed the D127Y variant to increase the $\mathrm{Ca}^{2+}$ sensitivity of reconstituted thin filaments, induce structural perturbations, and cause RCM phenotype [126]. In contrast to HCM and RCM mutations, DCM mutations in TNNI3 are less frequent. A2V was the first DCM-causing mutation discovered in TNNI3, causing an impaired TnI-TnT interaction. Functional studies have demonstrated that K36Q and N185K mutations decrease the maximal force and $\mathrm{Ca}^{2+}$ sensitivity of acto-myosin-S1 ATPase leading to the development of DCM phenotype [145]. 


\section{Troponin $\mathrm{T}$}

Cardiac, fast, and slow twitch isoforms of TnT are encoded by three different genes. $\mathrm{TnT}$ has two functional domains. The N-terminal domain $\mathrm{T} 1$ anchors $\mathrm{Tn}$ complex to the thin filament through its binding to Tm. The C-terminal domain T2 interacts with other Tn subunits ( $\mathrm{TnI}$ and $\mathrm{TnC}$ ) and Tm/actin. TNNT2 encodes the cardiac TnT and undergoes alternative splicing to produce four distinct cardiac isoforms in the human heart (cTnT1-cTnT4) [146]. PKC-dependent phosphorylation of cTnT and the alternative splicing of TNNT2 have been suggested to contribute to $\mathrm{Ca}^{2+}$-dependent regulation of muscle contraction [147]. Most HCM- and DCM-causing mutations in TNNT2 (reviewed in [139]) were found in the conserved middle or C-terminal region which contain TnI, TnC and tropomyosin binding sites [148]. Patients carrying HCM mutations in TNNT2 exhibited variable clinical outcomes and prognosis. Several mutations such as I179N, R92Q, R92W, R94L induced malignant phenotypes, however they were highly associated with sudden cardiac death and a short life span. Functional studies revealed the increase in $\mathrm{Ca}^{2+}$ sensitivity of myofilament force production. They suggested the interaction between TnT and $\mathrm{Tm}$ to be impaired leading to decreased inhibitory function of TnI on actin [149]. RCMcausing mutations in TNNT2 are rare. They demonstrated increased $\mathrm{Ca}^{2+}$ sensitivity and diminished ATPase inhibition and relaxation $[29,150]$. DCM-causing mutations (R131W, R141W, R205, $\Delta K 210, R 205 \mathrm{~L}$, and D270N) were shown to decrease $\mathrm{Ca}^{2+}$ sensitivity of force generation in skinned fibers [139]. R141W variant was reported to enhance TnT-Tm binding affinity leading to strong inhibitory effect of cTnI on the thin filament, and hence $\mathrm{Ca}^{2+}$ desensitization.

\section{Altered Cardiomyocyte Forces and Kinetics in Inherited Cardiomyopathies}

\section{1. $\mathrm{Ca}^{2+}$ Sensitivity}

Accumulating evidence has supported the association between altered $\mathrm{Ca}^{2+}$ sensitivity and inherited cardiomyopathies. Functional studies on sarcomeric mutations demonstrate that HCM and RCM mutations increase myofilament $\mathrm{Ca}^{2+}$ sensitivity and active force generation, while DCM mutations reduce it [151], hence opposing mechanical mechanisms contribute to the development of HCM, RCM and DCM [152]. The increased $\mathrm{Ca}^{2+}$ sensitivity of force development has been suggested to be the primary defect induced by HCM and RCM mutations. In general, higher $\mathrm{Ca}^{2+}$ sensitivity was detected in RCM compared with HCM mutations [153]. Several studies report HCM-associated mutations in sarcomeric proteins, especially in myosin [154,155], Tm [92] and cMyBPC [156,157], to cause perturbed myosin dynamics and disruption in the inhibitory regulation of actin leading to increased $\mathrm{Ca}^{2+}$ sensitivity. Such disturbances are attributed to mutation-inducedalterations in protein-protein interactions or protein haploinsufficiency, as discussed earlier in this review.

Perturbed actin-myosin attachments can strongly affect $\mathrm{Ca}^{2+}$ sensitivity. In vitro motility assays using thin filaments reconstituted with actin variants, such as $\mathrm{R} 312 \mathrm{H}$, showed altered myosin-driven motility and $\mathrm{Ca}^{2+}$ sensitivity [72]. Such alterations were attributed to the mutation-induced alterations in tropomyosin-actin interaction which inhibits strong actin-myosin binding in the absence of $\mathrm{Ca}^{2+}$ [72]. Furthermore, tropomyosin mutations that affect its binding with the myosin head, such as D137L and G126R, were shown to increase the maximal sliding velocity of regulated actin filaments in the in vitro motility assay at high $\mathrm{Ca}^{2+}$ concentrations and to increase the $\mathrm{Ca}^{2+}$ sensitivity of the actin-myosin interaction [158]. It has been suggested that theses mutations facilitate the displacement of tropomyosin from actin by a strong bond with myosin heads, allowing more myosin heads to bind actin, and hence increasing force production [158]. Another modulator of $\mathrm{Ca}^{2+}$ sensitivity is PKA-mediated phosphorylation of cTnI and cMyBPC (Figure 3). As shown in previous studies using HCM and end-stage heart failure myocardial samples, the increased $\mathrm{Ca}^{2+}$ sensitivity was correlated with reduced phosphorylation levels of cTnI and cMyBPC and could be reversed upon PKA treatment [159-161]. In addition to PKA, PKCand PKD-dependent phosphorylation of cTnI modulates $\mathrm{Ca}^{2+}$ sensitivity [162]. Structural 
and functional investigations suggested that, depending on the position of RCM and HCM mutations in CTnI, they either impair the accessibility of the kinases [163,164], or blunt the functional response upon phosphorylation [165]. Furthermore, the structural derangements caused by DCM mutations were found to uncouple troponin I phosphorylation from $\mathrm{Ca}^{2+}$ sensitivity changes $[72,95]$. Hence the altered response to $\beta$-adrenergic signaling and downstream phosphorylation of sarcomeric proteins play a major role in determining the myofilament $\mathrm{Ca}^{2+}$ sensitivity. Furthermore, the length-dependent increase in $\mathrm{Ca}^{2+}$ sensitivity is found to be reduced in human cardiac samples from patients carrying HCM and DCM mutations [166]. Length-dependent activation (LDA) is the main mechanism responsible for the Frank-Starling effect [167]. The perturbed LDA contributes to the myofilament dysfunction associated with DCM and HCM mutations.

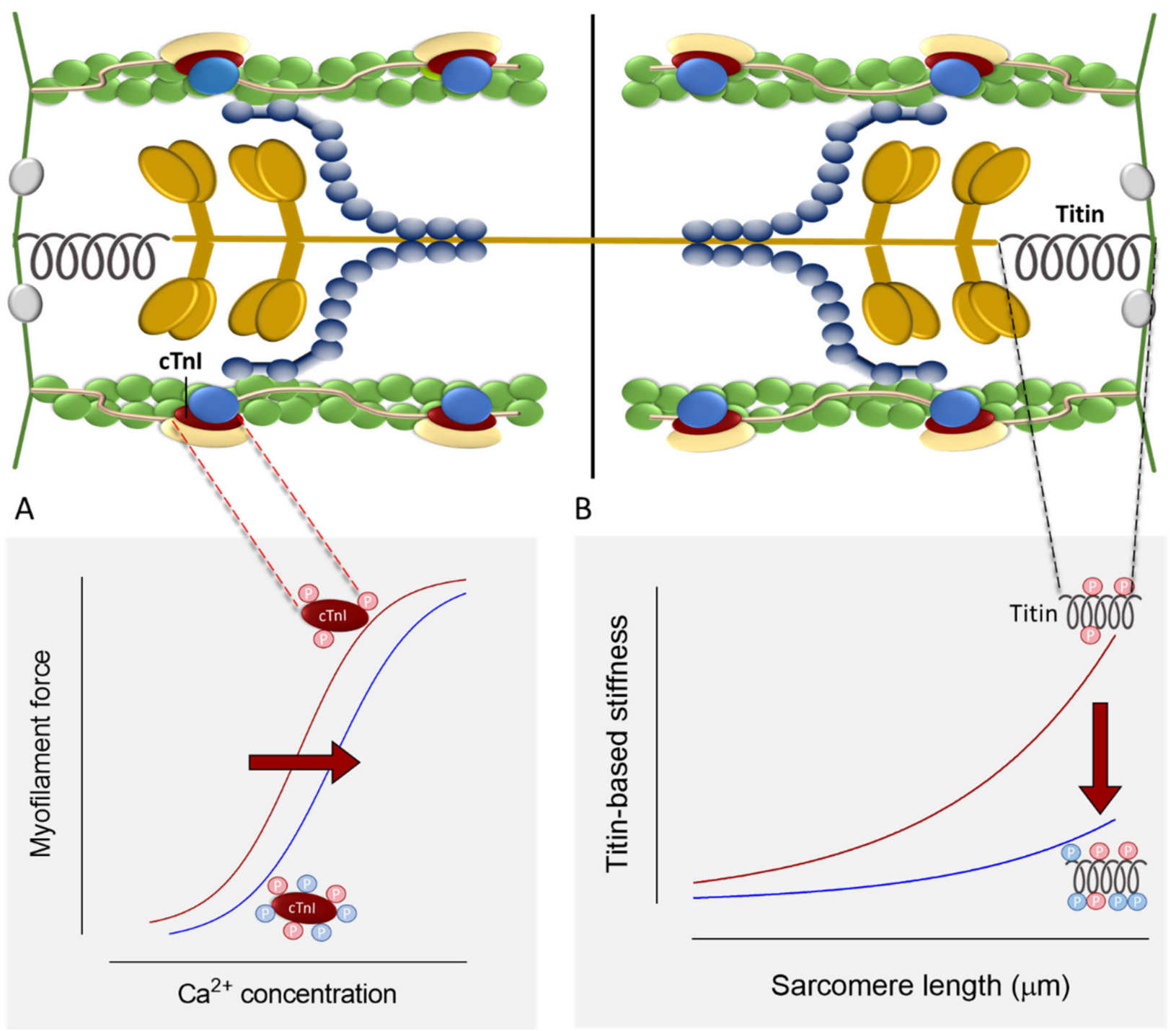

Figure 3. (A). Effects of cTnI phosphorylation on myocyte $\mathrm{Ca}^{2+}$ sensitivity. (B). Effects of titin phosphorylation on myocyte passive stiffness.

On the cellular level, enhanced $\mathrm{Ca}^{2+}$ sensitivity was shown to increase $\mathrm{Ca}^{2+}$-binding affinity to the thin filament $[168,169]$, causing delayed relaxation, hypercontractility, increased ATP utilization and arrhythmia [5]. On the other hand, $\mathrm{Ca}^{2+}$ desensitization in DCM accounts for systolic dysfunction and the initiation of ventricular dilation. The latter develops as a compensatory response to the decrease in stroke volume [5]. 


\subsection{Cross-Bridge Kinetics}

The basal acto-myosin-S1 ATPase activity was found to be enhanced in skinned fibers containing RCM and HCM mutations in $\mathrm{CTnI}[153,170]$, indicating the depressed relaxation properties of the myofilament which leads to the diastolic dysfunction. As previously discussed in this review, mutations in thick filament proteins that affect the sequestered state conformation of myosin alters the ATPase cycle and cross-bridge kinetics leading to hypocontractility (DCM) or hypercontractility (HCM and RCM). Both of which are associated with impaired systolic function. HCM mutations were found to be associated with reduced maximum $\mathrm{Ca}^{2+}$ activated force. Hoskins et al., 2010 suggested the structural alterations in myosin cause fast cross-bridge detachment leading to a loss in maximal force generation and a subsequent systolic dysfunction in HCM myocytes [161]. However, the study attributed the reduction in maximal force to changes secondary to the mutations, as no loss of myofibrils was detected [161]. Studies of animal models and human myocardial samples of HCM revealed the increase in ATP utilization for force generation (increased tension cost) $[171,172]$. ATP depletion impairs $\mathrm{Ca}^{2+}$ uptake via the high energy-dependent pump of the sarcoplasmic reticulum (SERCA2), leading to elevation in cytosolic free $\mathrm{Ca}^{2+}$ and $\mathrm{Ca}^{2+}$-dependent signaling. DCM-linked mutations also exhibit impaired $\mathrm{Ca}^{2+}$ cycling. As the $\mathrm{Ca}^{2+}$ sensitivity is decreased in DCM, higher levels of free cytosolic $\mathrm{Ca}^{2+}$ are required for tension generation, and $\mathrm{Ca}^{2+}$ dissociates rapidly from sarcomeres during relaxation [173]. The impaired $\mathrm{Ca}^{2+}$ cycling counts for the activation of signaling pathways that promote cardiac remodeling and growth [174].

\subsection{The Myocyte Passive Stiffness}

Interstitial fibrosis and myocyte disarray are responsible for ventricular stiffness observed in HCM and RCM [175]. However, myocardial stiffness can arise from the intrinsic stiffness of the myocyte itself. Titin is the major determinant of myocyte passive stiffness. Titin stiffness was shown to be positively correlated with active force in HCM and DCM [176]. HCM mutations lead to an increase in titin stiffness [177], whereas a decrease in titin stiffness was observed in DCM mutations [178]. These alterations are attributed to titin isoform switching. The increased expression of the compliant titin isoform (N2BA) associates with reduced myocardial stiffness and sarcomere rigidity found in eccentric remodeled hearts with systolic dysfunction, such as DCM [179-181], whereas reduced N2BA:N2B expression ratios were observed in HCM [182,183]. Such alterations could follow the primary defects caused by sarcomeric mutations. It has been previously demonstrated that during the progression of heart failure, the maladaptive response leads to the upregulation of N2BA at the expense of the N2B isoform, causing reduced passive stiffness, increased end diastolic volume, and hence ventricular dilation [178]. Along with isoform transitions, titin compliance is modulated by post-translational modifications including phosphorylation (Figure 3) [184]. In general, phosphorylation of the negatively charged N2Bus leads to a decrease, and phosphorylation of the positively charged PEVK leads to an increase of passive stiffness [58,185]. Previous studies have reported the altered PKA-, PKG-, PKC-, and CAMKII-dependent phosphorylation of titin, and hence the altered myocardial stiffness in DCM and HCM $[177,186]$.

\section{Therapies}

As no disease-specific treatments for familial cardiomyopathies exist, the management of the disease includes combination therapies to prevent heart failure progression and sudden cardiac death. Several novel agents have been shown to modulate sarcomere contractility such as the cardiac myosin inhibitor mavacamten (MYK-461). In HCM mice model carrying the MYH7 mutation, mavacamten was shown to reduce the ATPase activity of myosin, attenuate hypercontractility and profibrotic gene expression, and enhance relaxation [187]. $\mathrm{Ca}^{2+}$ sensitivity has also been targeted via agents that modulate actin-myosin interaction. Blebbistatin was shown to stabilize the thick filament off state and reduce actinmyosin cross-bridge formation and arrhythmia susceptibility in HCM [188,189]. Cardiac 
myosin activators such as omecamtiv mecarbil exhibited beneficial effects in DCM [190]. Omecamtiv mecarbil accelerates the transition of myosin from the weakly into the strongly actin-bound without altering the $\mathrm{Ca}^{2+}$ transient [191]. Another group of agents that modulate $\mathrm{Ca}^{2+}$ sensitivity is troponin-targeting agents. Levosimendan, a $\mathrm{Ca}^{2+}$ sensitizer, binds to the N-terminal domain of cTnC and stabilizes its open conformation [192]. Unlike most inotropes, levosimendan was demonstrated to enhance cardiac contractility without increasing oxygen demand [193] suggesting a beneficial therapeutic effect in DCM. The green tea catechin (-)-epigallocatechin gallate (EGCg) has been shown to bind to the C-terminal domain of $\mathrm{cTnC}$ and interfere with the $\mathrm{cTnC}-\mathrm{cTnI}$ interaction thereby decreasing $\mathrm{Ca}^{2+}$ sensitivity in myofilaments [194]. Furthermore, EGCg improved the diastolic function in an HCM mouse model [195]. In a recent study by us, we found levosimendan and EGCg to interact directly with actin and to improve the structural integrity of thin filaments reconstituted with troponin variants [126].

Clinical trials on several sarcomere contractility modulators showed moderate improvement in cardiac function (recently reviewed in [196]). Moreover, the adverse events caused by these drugs necessitates the development of analogous that are better tolerated.

Another evolving approach for the treatment of familial cardiomyopathy is gene therapy. HCM mutations in MYBPC3 that cause protein haploinsufficiency were managed by a viral transfer of wild-type $M Y B P C 3$ cDNA into human iPS derived cardiomyocyte [197]. The study reports the increased levels of wild type cMyBPC and improvement in cardiac function [197]. RNA interference has been used to silence the mutant RNA in a mouse model harboring MHY6 mutation and resulted in the prevention of HCM phenotype development [198]. CRISPR/Cas9 system in human embryos has been used to correct heterozygous mutation in MYBPC3 [199]. The study reports high efficiency and low adverse effects on embryonic development [199].

\section{Conclusions}

Inherited cardiomyopathies are known to cause heart failure and sudden cardiac death. Although the genotype-phenotype correlation is promoted via different pathological mechanisms, there is strong evidence that mutations in the sarcomeric proteins account for several defects in the contractile function. The impaired $\mathrm{Ca}^{2+}$ handling and the subsequent alterations in cardiomyocyte mechanics are common initiators of the disease. Understanding the molecular basis of the disease opens new avenues for the development of new therapies. The early awareness of the genetic defect, management of the risk factors, and prophylactic strategies play an important role in the clinical prognostication and the prevention of sudden cardiac death.

Funding: This work was supported by a restricted Research Grant by the DFG (HA 7512/2-1, HA 7512/2-4 to N.H.). The German Academic Exchange Service (DAAD) supported R.H. and the Heinrich und Alma Vogelsang Stiftung H.B.

Institutional Review Board Statement: Not applicable.

Informed Consent Statement: Not applicable.

Data Availability Statement: Not applicable.

Conflicts of Interest: The authors declare no conflict of interest. 


\section{References}

1. Semsarian, C.; Ingles, J.; Maron, M.S.; Maron, B.J. New Perspectives on the Prevalence of Hypertrophic Cardiomyopathy. J. Am. Coll. Cardiol. 2015, 65, 1249-1254. [CrossRef] [PubMed]

2. Marian, A.J.; Braunwald, E. Hypertrophic Cardiomyopathy: Genetics, Pathogenesis, Clinical Manifestations, Diagnosis, and Therapy. Circ. Res. 2017, 121, 749-770. [CrossRef] [PubMed]

3. Hershberger, R.E.; Hedges, D.J.; Morales, A. Dilated Cardiomyopathy: The Complexity of a Diverse Genetic Architecture. Nat. Rev. Cardiol. 2013, 10, 531-547. [CrossRef]

4. Elliott, P.; Andersson, B.; Arbustini, E.; Bilinska, Z.; Cecchi, F.; Charron, P.; Dubourg, O.; Kühl, U.; Maisch, B.; McKenna, W.J.; et al. Classification of the Cardiomyopathies: A Position Statement from the European Society of Cardiology Working Group on Myocardial and Pericardial Diseases. Eur. Heart J. 2008, 29, 270-276. [CrossRef]

5. Fatkin, D.; Graham, R.M. Molecular Mechanisms of Inherited Cardiomyopathies. Physiol. Rev. 2002, 82, 945-980. [CrossRef] [PubMed]

6. Richards, C.S.; Bale, S.; Bellissimo, D.B.; Das, S.; Grody, W.W.; Hegde, M.R.; Lyon, E.; Ward, B.E. ACMG Recommendations for Standards for Interpretation and Reporting of Sequence Variations: Revisions 2007. Genet. Med. 2008, 10, 294-300. [CrossRef]

7. Richards, S.; Aziz, N.; Bale, S.; Bick, D.; Das, S.; Gastier-Foster, J.; Grody, W.W.; Hegde, M.; Lyon, E.; Spector, E.; et al. Standards and Guidelines for the Interpretation of Sequence Variants: A Joint Consensus Recommendation of the American College of Medical Genetics and Genomics and the Association for Molecular Pathology. Genet. Med. 2015, 17, 405-423. [CrossRef]

8. Maron, B.J. Hypertrophic Cardiomyopathy: A Systematic Review. JAMA 2002, 287, 1308-1320. [CrossRef]

9. Finocchiaro, G.; Papadakis, M.; Tanzarella, G.; Dhutia, H.; Miles, C.; Tome, M.; Behr, E.R.; Sharma, S.; Sheppard, M.N. Sudden Death Can Be the First Manifestation of Hypertrophic Cardiomyopathy: Data From a United Kingdom Pathology Registry. JACC Clin. Electrophysiol. 2019, 5, 252-254. [CrossRef]

10. Maron, B.J.; Towbin, J.A.; Thiene, G.; Antzelevitch, C.; Corrado, D.; Arnett, D.; Moss, A.J.; Seidman, C.E.; Young, J.B. Contemporary Definitions and Classification of the Cardiomyopathies. Circulation 2006, 113, 1807-1816. [CrossRef]

11. Marstrand, P.; Han, L.; Day, S.M.; Olivotto, I.; Ashley, E.A.; Michels, M.; Pereira, A.C.; Wittekind, S.G.; Helms, A.; Saberi, S.; et al. Hypertrophic Cardiomyopathy with Left Ventricular Systolic Dysfunction. Circulation 2020, 141, 1371-1383. [CrossRef] [PubMed]

12. Thierfelder, L.; Watkins, H.; MacRae, C.; Lamas, R.; McKenna, W.; Vosberg, H.-P.; Seldman, J.G.; Seidman, C.E. $\alpha$-Tropomyosin and Cardiac Troponin T Mutations Cause Familial Hypertrophic Cardiomyopathy: A Disease of the Sarcomere. Cell 1994, 77, 701-712. [CrossRef]

13. Teekakirikul, P.; Zhu, W.; Huang, H.C.; Fung, E. Hypertrophic Cardiomyopathy: An Overview of Genetics and Management. Biomolecules 2019, 9, 878. [CrossRef]

14. Dec, G.W.; Fuster, V. Idiopathic Dilated Cardiomyopathy. N. Engl. J. Med. 1994, 331, 1564-1575. [CrossRef]

15. Weintraub, R.G.; Semsarian, C.; Macdonald, P. Dilated Cardiomyopathy. Lancet 2017, 390, 400-414. [CrossRef]

16. Sandoval, Y.; Januzzi, J.L.J.; Jaffe, A.S. Cardiac Troponin for Assessment of Myocardial Injury in COVID-19: JACC Review Topic of the Week. J. Am. Coll. Cardiol. 2020, 76, 1244-1258. [CrossRef] [PubMed]

17. Grünig, E.; Tasman, J.A.; Kücherer, H.; Franz, W.; Kübler, W.; Katus, H.A. Frequency and Phenotypes of Familial Dilated Cardiomyopathy. J. Am. Coll. Cardiol. 1998, 31, 186-194. [CrossRef]

18. Arbustini, E.; Narula, N.; Tavazzi, L.; Serio, A.; Grasso, M.; Favalli, V.; Bellazzi, R.; Tajik, J.A.; Bonow, R.O.; Fuster, V.; et al. The MOGE(S) Classification of Cardiomyopathy for Clinicians. J. Am. Coll. Cardiol. 2014, 64, 304-318. [CrossRef]

19. Arbustini, E.; Morbini, P.; Pilotto, A.; Gavazzi, A.; Tavazzi, L. Genetics of Idiopathic Dilated Cardiomyopathy. Herz 2000, 25, 156-160. [CrossRef] [PubMed]

20. Sweet, M.; Taylor, M.R.G.; Mestroni, L. Diagnosis, Prevalence, and Screening of Familial Dilated Cardiomyopathy. Expert Opin. Orphan Drugs 2015, 3, 869-876. [CrossRef]

21. Brauch, K.M.; Karst, M.L.; Herron, K.J.; de Andrade, M.; Pellikka, P.A.; Rodeheffer, R.J.; Michels, V.V.; Olson, T.M. Mutations in Ribonucleic Acid Binding Protein Gene Cause Familial Dilated Cardiomyopathy. J. Am. Coll. Cardiol. 2009, 54, 930-941. [CrossRef] [PubMed]

22. Norton, N.; Li, D.; Rieder, M.J.; Siegfried, J.D.; Rampersaud, E.; Züchner, S.; Mangos, S.; Gonzalez-Quintana, J.; Wang, L.; McGee, S.; et al. Genome-Wide Studies of Copy Number Variation and Exome Sequencing Identify Rare Variants in BAG3 as a Cause of Dilated Cardiomyopathy. Am. J. Hum. Genet. 2011, 88, 273-282. [CrossRef] [PubMed]

23. Orphanou, N.; Papatheodorou, E.; Anastasakis, A. Dilated Cardiomyopathy in the Era of Precision Medicine: Latest Concepts and Developments. Heart Fail. Rev. 2021. [CrossRef] [PubMed]

24. Lewis, A.B. Clinical Profile and Outcome of Restrictive Cardiomyopathy in Children. Am. Heart J. 1992, 123, 1589-1593. [CrossRef]

25. Nihoyannopoulos, P.; Dawson, D. Restrictive Cardiomyopathies. Eur. J. Echocardiogr. 2009, 10, iii23-iii33. [CrossRef] [PubMed]

26. Brown, K.N.; Pendela, V.S.; Diaz, R.R. Restrictive Cardiomyopathy; StatPearls Publishing: Treasure Island, FL, USA, 2021. [PubMed]

27. Angelini, A.; Calzolari, V.; Thiene, G.; Boffa, G.M.; Valente, M.; Daliento, L.; Basso, C.; Calabrese, F.; Razzolini, R.; Livi, U.; et al. Morphologic Spectrum of Primary Restrictive Cardiomyopathy. Am. J. Cardiol. 1997, 80, 1046-1050. [CrossRef]

28. Vio, R.; Angelini, A.; Basso, C.; Cipriani, A.; Zorzi, A.; Melacini, P.; Thiene, G.; Rampazzo, A.; Corrado, D.; Calore, C. Hypertrophic Cardiomyopathy and Primary Restrictive Cardiomyopathy: Similarities, Differences and Phenocopies. J. Clin. Med. 2021, $10,1954$. [CrossRef] 
29. Cimiotti, D.; Budde, H.; Hassoun, R.; Jaquet, K. Genetic Restrictive Cardiomyopathy: Causes and Consequences-An Integrative Approach. Int. J. Mol. Sci. 2021, 22, 558. [CrossRef] [PubMed]

30. Fontaine, G.; Fontaliran, F.; Frank, R. Arrhythmogenic Right Ventricular Cardiomyopathies: Clinical Forms and Main Differential Diagnoses. Circulation 1998, 97, 1532-1535. [CrossRef]

31. Corrado, D.; Basso, C. Arrhythmogenic Left Ventricular Cardiomyopathy. Heart 2021. [CrossRef]

32. Corrado, D.; Basso, C.; Judge, D.P. Arrhythmogenic Cardiomyopathy. Circ. Res. 2017, 121, 784-802. [CrossRef] [PubMed]

33. Parker, F.; Peckham, M. Disease Mutations in Striated Muscle Myosins. Biophys. Rev. 2020, 12, 887-894. [CrossRef]

34. Walsh, R.; Thomson, K.L.; Ware, J.S.; Funke, B.H.; Woodley, J.; McGuire, K.J.; Mazzarotto, F.; Blair, E.; Seller, A.; Taylor, J.C.; et al. Reassessment of Mendelian Gene Pathogenicity Using 7855 Cardiomyopathy Cases and 60,706 Reference Samples. Genet. Med. 2017, 19, 192-203. [CrossRef]

35. Adhikari, A.S.; Kooiker, K.B.; Sarkar, S.S.; Liu, C.; Bernstein, D.; Spudich, J.A.; Ruppel, K.M. Early-Onset Hypertrophic Cardiomyopathy Mutations Significantly Increase the Velocity, Force, and Actin-Activated ATPase Activity of Human $\beta$-Cardiac Myosin. Cell Rep. 2016, 17, 2857-2864. [CrossRef]

36. Kawana, M.; Sarkar, S.S.; Sutton, S.; Ruppel, K.M.; Spudich, J.A. Biophysical Properties of Human $\beta$-Cardiac Myosin with Converter Mutations That Cause Hypertrophic Cardiomyopathy. Sci. Adv. 2017, 3, e1601959. [CrossRef] [PubMed]

37. Sommese, R.F.; Sung, J.; Nag, S.; Sutton, S.; Deacon, J.C.; Choe, E.; Leinwand, L.A.; Ruppel, K.; Spudich, J.A. Molecular Consequences of the R453C Hypertrophic Cardiomyopathy Mutation on Human $\beta$-Cardiac Myosin Motor Function. Proc. Natl. Acad. Sci. USA 2013, 110, 12607-12612. [CrossRef]

38. Nag, S.; Sommese, R.F.; Ujfalusi, Z.; Combs, A.; Langer, S.; Sutton, S.; Leinwand, L.A.; Geeves, M.A.; Ruppel, K.M.; Spudich, J.A. Contractility Parameters of Human $\beta$-Cardiac Myosin with the Hypertrophic Cardiomyopathy Mutation R403Q Show Loss of Motor Function. Sci. Adv. 2015, 1, e1500511. [CrossRef]

39. Al-Khayat, H.A.; Kensler, R.W.; Squire, J.M.; Marston, S.B.; Morris, E.P. Atomic Model of the Human Cardiac Muscle Myosin Filament. Proc. Natl. Acad. Sci. USA 2013, 110, 318-323. [CrossRef]

40. Adhikari, A.S.; Trivedi, D.V.; Sarkar, S.S.; Song, D.; Kooiker, K.B.; Bernstein, D.; Spudich, J.A.; Ruppel, K.M. $\beta$-Cardiac Myosin Hypertrophic Cardiomyopathy Mutations Release Sequestered Heads and Increase Enzymatic Activity. Nat. Commun. 2019, 10, 2685. [CrossRef] [PubMed]

41. Vander Roest, A.S.; Liu, C.; Morck, M.M.; Kooiker, K.B.; Jung, G.; Song, D.; Dawood, A.; Jhingran, A.; Pardon, G.; Ranjbarvaziri, S.; et al. Hypertrophic Cardiomyopathy $\beta$-Cardiac Myosin Mutation (P710R) Leads to Hypercontractility by Disrupting Super Relaxed State. Proc. Natl. Acad. Sci. USA 2021, 118, e2025030118. [CrossRef]

42. Harris, S.P.; Lyons, R.G.; Bezold, K.L.; Robbins, J.; Seidman, C.; Watkins, H. In the Thick of It. Circ. Res. 2011, 108, 751-764. [CrossRef]

43. Ujfalusi, Z.; Vera, C.D.; Mijailovich, S.M.; Svicevic, M.; Yu, E.C.; Kawana, M.; Ruppel, K.M.; Spudich, J.A.; Geeves, M.A.; Leinwand, L.A. Dilated Cardiomyopathy Myosin Mutants Have Reduced Force-Generating Capacity. J. Biol. Chem. 2018, 293, 9017-9029. [CrossRef]

44. Trujillo, A.S.; Hsu, K.H.; Puthawala, J.; Viswanathan, M.C.; Loya, A.; Irving, T.C.; Cammarato, A.; Swank, D.M.; Bernstein, S.I. Myosin Dilated Cardiomyopathy Mutation S532P Disrupts Actomyosin Interactions, Leading to Altered Muscle Kinetics, Reduced Locomotion, and Cardiac Dilation in Drosophila. Mol. Biol. Cell 2021. [CrossRef] [PubMed]

45. Spudich, J.A. Hypertrophic and Dilated Cardiomyopathy: Four Decades of Basic Research on Muscle Lead to Potential Therapeutic Approaches to These Devastating Genetic Diseases. Biophys. J. 2014, 106, 1236-1249. [CrossRef]

46. Cimiotti, D.; Fujita-Becker, S.; Möhner, D.; Smolina, N.; Budde, H.; Wies, A.; Morgenstern, L.; Gudkova, A.; Sejersen, T.; Sjöberg, G.; et al. Infantile Restrictive Cardiomyopathy: CTnI-R170G/W Impair the Interplay of Sarcomeric Proteins and the Integrity of Thin Filaments. PLoS ONE 2020, 15, e0229227. [CrossRef] [PubMed]

47. Ponnam, S.; Sevrieva, I.R.; Sun, Y.-B.; Irving, M.; Kampourakis, T. Site-Specific Phosphorylation of Myosin Binding Protein-C Coordinates Thin and Thick Filament Activation in Cardiac Muscle. Proc. Natl. Acad. Sci. USA 2019, 116, 15485-15494. [CrossRef] [PubMed]

48. Tong, C.W.; Stelzer, J.E.; Greaser, M.L.; Powers, P.A.; Moss, R.L. Acceleration of Cross-bridge Kinetics by Protein Kinase A Phosphorylation of Cardiac Myosin Binding Protein C Modulates Cardiac Function. Circ. Res. 2008, 103, 974-982. [CrossRef]

49. Daehmlow, S.; Erdmann, J.; Knueppel, T.; Gille, C.; Froemmel, C.; Hummel, M.; Hetzer, R.; Regitz-Zagrosek, V. Novel Mutations in Sarcomeric Protein Genes in Dilated Cardiomyopathy. Biochem. Biophys. Res. Commun. 2002, 298, 116-120. [CrossRef]

50. Yotti, R.; Seidman, C.E.; Seidman, J.G. Advances in the Genetic Basis and Pathogenesis of Sarcomere Cardiomyopathies. Annu. Rev. Genom. Hum. Genet. 2019, 20, 129-153. [CrossRef] [PubMed]

51. Carrier, L.; Mearini, G.; Stathopoulou, K.; Cuello, F. Cardiac Myosin-Binding Protein C (MYBPC3) in Cardiac Pathophysiology. Gene 2015, 573, 188-197. [CrossRef]

52. Glazier, A.A.; Thompson, A.; Day, S.M. Allelic Imbalance and Haploinsufficiency in MYBPC3-Linked Hypertrophic Cardiomyopathy. Pflugers Arch. 2019, 471, 781-793. [CrossRef] [PubMed]

53. Moolman-Smook, J.; Flashman, E.; de Lange, W.; Li, Z.; Corfield, V.; Redwood, C.; Watkins, H. Identification of Novel Interactions Between Domains of Myosin Binding Protein-C That Are Modulated by Hypertrophic Cardiomyopathy Missense Mutations. Circ. Res. 2002, 91, 704-711. [CrossRef] 
54. Suay-Corredera, C.; Pricolo, M.R.; Herrero-Galán, E.; Velázquez-Carreras, D.; Sánchez-Ortiz, D.; García-Giustiniani, D.; Delgado, J.; Galano-Frutos, J.J.; García-Cebollada, H.; Vilches, S.; et al. Protein Haploinsufficiency Drivers Identify MYBPC3 Variants That Cause Hypertrophic Cardiomyopathy. J. Biol. Chem. 2021, 297, 100854. [CrossRef]

55. Ito, K.; Patel, P.N.; Gorham, J.M.; McDonough, B.; DePalma, S.R.; Adler, E.E.; Lam, L.; MacRae, C.A.; Mohiuddin, S.M.; Fatkin, D.; et al. Identification of Pathogenic Gene Mutations in LMNA and MYBPC3 That Alter RNA Splicing. Proc. Natl. Acad. Sci. USA 2017, 114, 7689-7694. [CrossRef] [PubMed]

56. van Dijk, S.J.; Dooijes, D.; dos Remedios, C.; Michels, M.; Lamers, J.M.J.; Winegrad, S.; Schlossarek, S.; Carrier, L.; ten Cate, F.J.; Stienen, G.J.M.; et al. Cardiac Myosin-Binding Protein C Mutations and Hypertrophic Cardiomyopathy: Haploinsufficiency, Deranged Phosphorylation, and Cardiomyocyte Dysfunction. Circulation 2009, 119, 1473-1483. [CrossRef]

57. LeWinter, M.M.; Granzier, H. Cardiac Titin. Circulation 2010, 121, 2137-2145. [CrossRef]

58. Linke, W.A.; Hamdani, N. Gigantic Business: Titin Properties and Function through Thick and Thin. Circ. Res. 2014, 114, 1052-1068. [CrossRef] [PubMed]

59. Peled, Y.; Gramlich, M.; Yoskovitz, G.; Feinberg, M.S.; Afek, A.; Polak-Charcon, S.; Pras, E.; Sela, B.-A.; Konen, E.; Weissbrod, O.; et al. Titin Mutation in Familial Restrictive Cardiomyopathy. Int. J. Cardiol. 2014, 171, 24-30. [CrossRef]

60. Satoh, M.; Takahashi, M.; Sakamoto, T.; Hiroe, M.; Marumo, F.; Kimura, A. Structural Analysis of the Titin Gene in Hypertrophic Cardiomyopathy: Identification of a Novel Disease Gene. Biochem. Biophys. Res. Commun. 1999, 262, 411-417. [CrossRef]

61. Taylor, M.; Graw, S.; Sinagra, G.; Barnes, C.; Slavov, D.; Brun, F.; Pinamonti, B.; Salcedo, E.E.; Sauer, W.; Pyxaras, S.; et al. Genetic Variation in Titin in Arrhythmogenic Right Ventricular Cardiomyopathy-Overlap Syndromes. Circulation 2011, 124, 876-885. [CrossRef]

62. Begay, R.L.; Graw, S.; Sinagra, G.; Merlo, M.; Slavov, D.; Gowan, K.; Jones, K.L.; Barbati, G.; Spezzacatene, A.; Brun, F.; et al. Role of Titin Missense Variants in Dilated Cardiomyopathy. J. Am. Heart Assoc. 2015, 4, e002645. [CrossRef] [PubMed]

63. Roberts, A.M.; Ware, J.S.; Herman, D.S.; Schafer, S.; Baksi, J.; Bick, A.G.; Buchan, R.J.; Walsh, R.; John, S.; Wilkinson, S.; et al. Integrated Allelic, Transcriptional, and Phenomic Dissection of the Cardiac Effects of Titin Truncations in Health and Disease. Sci. Transl. Med. 2015, 7, 270ra6. [CrossRef]

64. Herman, D.S.; Lam, L.; Taylor, M.R.G.; Wang, L.; Teekakirikul, P.; Christodoulou, D.; Conner, L.; DePalma, S.R.; McDonough, B.; Sparks, E.; et al. Truncations of Titin Causing Dilated Cardiomyopathy. N. Engl. J. Med. 2012, 366, 619-628. [CrossRef] [PubMed]

65. Hinson, J.T.; Chopra, A.; Nafissi, N.; Polacheck, W.J.; Benson, C.C.; Swist, S.; Gorham, J.; Yang, L.; Schafer, S.; Sheng, C.C.; et al. Heart Disease. Titin Mutations in IPS Cells Define Sarcomere Insufficiency as a Cause of Dilated Cardiomyopathy. Science 2015, 349, 982-986. [CrossRef]

66. Golbus, J.R.; Puckelwartz, M.J.; Fahrenbach, J.P.; Dellefave-Castillo, L.M.; Wolfgeher, D.; McNally, E.M. Population-Based Variation in Cardiomyopathy Genes. Circ. Cardiovasc. Genet. 2012, 5, 391-399. [CrossRef] [PubMed]

67. Radke, M.H.; Polack, C.; Methawasin, M.; Fink, C.; Granzier, H.L.; Gotthardt, M. Deleting Full Length Titin Versus the Titin M-Band Region Leads to Differential Mechanosignaling and Cardiac Phenotypes. Circulation 2019, 139, 1813-1827. [CrossRef]

68. Schafer, S.; de Marvao, A.; Adami, E.; Fiedler, L.R.; Ng, B.; Khin, E.; Rackham, O.J.L.; van Heesch, S.; Pua, C.J.; Kui, M.; et al. Titin-Truncating Variants Affect Heart Function in Disease Cohorts and the General Population. Nat. Genet. 2017, $49,46-53$. [CrossRef]

69. Schick, R.; Mekies, L.N.; Shemer, Y.; Eisen, B.; Hallas, T.; Jehuda, R.B.; Ben-Ari, M.; Szantai, A.; Willi, L.; Shulman, R.; et al. Functional Abnormalities in Induced Pluripotent Stem Cell-Derived Cardiomyocytes Generated from Titin-Mutated Patients with Dilated Cardiomyopathy. PLoS ONE 2018, 13, e0205719. [CrossRef]

70. Chopra, A.; Kutys, M.L.; Zhang, K.; Polacheck, W.J.; Sheng, C.C.; Luu, R.J.; Eyckmans, J.; Hinson, J.T.; Seidman, J.G.; Seidman, C.E.; et al. Force Generation via $\beta$-Cardiac Myosin, Titin, and $\alpha$-Actinin Drives Cardiac Sarcomere Assembly from Cell-Matrix Adhesions. Dev. Cell 2018, 44, 87-96.e5. [CrossRef]

71. Adams, M.; Fleming, J.R.; Riehle, E.; Zhou, T.; Zacharchenko, T.; Markovic, M.; Mayans, O. Scalable, Non-Denaturing Purification of Phosphoproteins Using Ga(3+)-IMAC: N2A and M1M2 Titin Components as Study Case. Protein J. 2019, 38, 181-189. [CrossRef]

72. Parker, F.; Baboolal, T.G.; Peckham, M. Actin Mutations and Their Role in Disease. Int. J. Mol. Sci. 2020, 21, 3371. [CrossRef]

73. Bookwalter, C.S.; Trybus, K.M. Functional Consequences of a Mutation in an Expressed Human $\alpha$-Cardiac Actin at a Site Implicated in Familial Hypertrophic Cardiomyopathy. J. Biol. Chem. 2006, 281, 16777-16784. [CrossRef] [PubMed]

74. Despond, E.A.; Dawson, J.F. Classifying Cardiac Actin Mutations Associated with Hypertrophic Cardiomyopathy. Front. Physiol. 2018, 9, 405. [CrossRef]

75. Viswanathan, M.C.; Schmidt, W.; Rynkiewicz, M.J.; Agarwal, K.; Gao, J.; Katz, J.; Lehman, W.; Cammarato, A. Distortion of the Actin A-Triad Results in Contractile Disinhibition and Cardiomyopathy. Cell Rep. 2017, 20, 2612-2625. [CrossRef] [PubMed]

76. Mundia, M.M.; Demers, R.W.; Chow, M.L.; Perieteanu, A.A.; Dawson, J.F. Subdomain Location of Mutations in Cardiac Actin Correlate with Type of Functional Change. PLoS ONE 2012, 7, e36821. [CrossRef] [PubMed]

77. Erdmann, C.; Hassoun, R.; Schmitt, S.; Kikuti, C.; Houdusse, A.; Mazur, A.J.; Mügge, A.; Hamdani, N.; Geyer, M.; Jaquet, K.; et al. Integration of Cardiac Actin Mutants Causing Hypertrophic (p.A295S) and Dilated Cardiomyopathy (p.R312H and p.E361G) into Cellular Structures. Antioxidants 2021, 10, 1082. [CrossRef]

78. Olson, T.M.; Michels, V.V.; Thibodeau, S.N.; Tai, Y.S.; Keating, M.T. Actin Mutations in Dilated Cardiomyopathy, a Heritable Form of Heart Failure. Science 1998, 280, 750-752. [CrossRef] 
79. Olson, T.M.; Doan, T.P.; Kishimoto, N.Y.; Whitby, F.G.; Ackerman, M.J.; Fananapazir, L. Inherited and de Novo Mutations in the Cardiac Actin Gene Cause Hypertrophic Cardiomyopathy. J. Mol. Cell. Cardiol. 2000, 32, 1687-1694. [CrossRef]

80. Mogensen, J.; Perrot, A.; Andersen, P.S.; Havndrup, O.; Klausen, I.C.; Christiansen, M.; Bross, P.; Egeblad, H.; Bundgaard, H.; Osterziel, K.J.; et al. Clinical and Genetic Characteristics of Alpha Cardiac Actin Gene Mutations in Hypertrophic Cardiomyopathy. J. Med. Genet. 2004, 41, e10. [CrossRef]

81. Mogensen, J.; Klausen, I.C.; Pedersen, A.K.; Egeblad, H.; Bross, P.; Kruse, T.A.; Gregersen, N.; Hansen, P.S.; Baandrup, U.; Borglum, A.D. Alpha-Cardiac Actin Is a Novel Disease Gene in Familial Hypertrophic Cardiomyopathy. J. Clin. Investig. 1999, 103, R39-R43. [CrossRef]

82. Kaski, J.P.; Syrris, P.; Esteban, M.T.T.; Jenkins, S.; Pantazis, A.; Deanfield, J.E.; McKenna, W.J.; Elliott, P.M. Prevalence of Sarcomere Protein Gene Mutations in Preadolescent Children With Hypertrophic Cardiomyopathy. Circ. Cardiovasc. Genet. $2009,2,436-441$. [CrossRef]

83. Olivotto, I.; Girolami, F.; Ackerman, M.J.; Nistri, S.; Bos, J.M.; Zachara, E.; Ommen, S.R.; Theis, J.L.; Vaubel, R.A.; Re, F.; et al. Myofilament Protein Gene Mutation Screening and Outcome of Patients With Hypertrophic Cardiomyopathy. Mayo Clin. Proc. 2008, 83, 630-638. [CrossRef]

84. Van Driest, S.L.; Ellsworth, E.G.; Ommen, S.R.; Tajik, A.J.; Gersh, B.J.; Ackerman, M.J. Prevalence and Spectrum of Thin Filament Mutations in an Outpatient Referral Population With Hypertrophic Cardiomyopathy. Circulation 2003, 108, 445-451. [CrossRef]

85. Morita, H.; Rehm, H.L.; Menesses, A.; McDonough, B.; Roberts, A.E.; Kucherlapati, R.; Towbin, J.A.; Seidman, J.G.; Seidman, C.E. Shared Genetic Causes of Cardiac Hypertrophy in Children and Adults. N. Engl. J. Med. 2008, 358, 1899-1908. [CrossRef]

86. Yamada, Y.; Namba, K.; Fujii, T. Cardiac Muscle Thin Filament Structures Reveal Calcium Regulatory Mechanism. Nat. Commun. 2020, 11, 153. [CrossRef] [PubMed]

87. McKillop, D.F.; Geeves, M.A. Regulation of the Interaction between Actin and Myosin Subfragment 1: Evidence for Three States of the Thin Filament. Biophys. J. 1993, 65, 693-701. [CrossRef]

88. Parry, D.A.D.; Squire, J.M. Structural Role of Tropomyosin in Muscle Regulation: Analysis of the X-Ray Diffraction Patterns from Relaxed and Contracting Muscles. J. Mol. Biol. 1973, 75, 33-55. [CrossRef]

89. Galińska-Rakoczy, A.; Engel, P.; Xu, C.; Jung, H.; Craig, R.; Tobacman, L.S.; Lehman, W. Structural Basis for the Regulation of Muscle Contraction by Troponin and Tropomyosin. J. Mol. Biol. 2008, 379, 929-935. [CrossRef]

90. Bai, F.; Wang, L.; Kawai, M. A Study of Tropomyosin's Role in Cardiac Function and Disease Using Thin-Filament Reconstituted Myocardium. J. Muscle Res. Cell Motil. 2013, 34, 295-310. [CrossRef] [PubMed]

91. Bai, F.; Weis, A.; Takeda, A.K.; Chase, P.B.; Kawai, M. Enhanced Active Cross-Bridges during Diastole: Molecular Pathogenesis of Tropomyosin's HCM Mutations. Biophys. J. 2011, 100, 1014-1023. [CrossRef]

92. Matyushenko, A.M.; Levitsky, D.I. Molecular Mechanisms of Pathologies of Skeletal and Cardiac Muscles Caused by Point Mutations in the Tropomyosin Genes. Biochemistry 2020, 85, S20-S33. [CrossRef]

93. Moore, J.R.; Campbell, S.G.; Lehman, W. Structural Determinants of Muscle Thin Filament Cooperativity. Arch. Biochem. Biophys. 2016, 594, 8-17. [CrossRef]

94. Redwood, C.; Robinson, P. Alpha-Tropomyosin Mutations in Inherited Cardiomyopathies. J. Muscle Res. Cell Motil. 2013, 34, 285-294. [CrossRef] [PubMed]

95. Memo, M.; Leung, M.-C.; Ward, D.G.; dos Remedios, C.; Morimoto, S.; Zhang, L.; Ravenscroft, G.; McNamara, E.; Nowak, K.J.; Marston, S.B.; et al. Familial Dilated Cardiomyopathy Mutations Uncouple Troponin I Phosphorylation from Changes in Myofibrillar $\mathrm{Ca}^{2}+$ Sensitivity. Cardiovasc. Res. 2013, 99, 65-73. [CrossRef]

96. Olson, T.M.; Kishimoto, N.Y.; Whitby, F.G.; Michels, V.V. Mutations That Alter the Surface Charge of Alpha-Tropomyosin Are Associated with Dilated Cardiomyopathy. J. Mol. Cell. Cardiol. 2001, 33, 723-732. [CrossRef]

97. van de Meerakker, J.B.A.; Christiaans, I.; Barnett, P.; Lekanne Deprez, R.H.; Ilgun, A.; Mook, O.R.F.; Mannens, M.M.A.M.; Lam, J.; Wilde, A.A.M.; Moorman, A.F.M.; et al. A Novel Alpha-Tropomyosin Mutation Associates with Dilated and Non-Compaction Cardiomyopathy and Diminishes Actin Binding. Biochim. Biophys. Acta 2013, 1833, 833-839. [CrossRef] [PubMed]

98. Lakdawala, N.K.; Dellefave, L.; Redwood, C.S.; Sparks, E.; Cirino, A.L.; Depalma, S.; Colan, S.D.; Funke, B.; Zimmerman, R.S.; Robinson, P.; et al. Familial Dilated Cardiomyopathy Caused by an Alpha-Tropomyosin Mutation: The Distinctive Natural History of Sarcomeric Dilated Cardiomyopathy. J. Am. Coll. Cardiol. 2010, 55, 320-329. [CrossRef] [PubMed]

99. Lakdawala, N.K.; Funke, B.H.; Baxter, S.; Cirino, A.L.; Roberts, A.E.; Judge, D.P.; Johnson, N.; Mendelsohn, N.J.; Morel, C.; Care, M.; et al. Genetic Testing for Dilated Cardiomyopathy in Clinical Practice. J. Card. Fail. 2012, 18, 296-303. [CrossRef]

100. Hershberger, R.E.; Norton, N.; Morales, A.; Li, D.; Siegfried, J.D.; Gonzalez-Quintana, J. Coding Sequence Rare Variants Identified in MYBPC3, MYH6, TPM1, TNNC1, and TNNI3 from 312 Patients with Familial or Idiopathic Dilated Cardiomyopathy. Circ. Cardiovasc. Genet. 2010, 3, 155-161. [CrossRef]

101. van Spaendonck-Zwarts, K.Y.; van Rijsingen, I.A.W.; van den Berg, M.P.; Lekanne Deprez, R.H.; Post, J.G.; van Mil, A.M.; Asselbergs, F.W.; Christiaans, I.; van Langen, I.M.; Wilde, A.A.M.; et al. Genetic Analysis in 418 Index Patients with Idiopathic Dilated Cardiomyopathy: Overview of 10 Years' Experience. Eur. J. Heart Fail. 2013, 15, 628-636. [CrossRef]

102. Probst, S.; Oechslin, E.; Schuler, P.; Greutmann, M.; Boyé, P.; Knirsch, W.; Berger, F.; Thierfelder, L.; Jenni, R.; Klaassen, S. Sarcomere Gene Mutations in Isolated Left Ventricular Noncompaction Cardiomyopathy Do Not Predict Clinical Phenotype. Circ. Cardiovasc. Genet. 2011, 4, 367-374. [CrossRef] 
103. Frisso, G.; Limongelli, G.; Pacileo, G.; Del Giudice, A.; Forgione, L.; Calabrò, P.; Iacomino, M.; Detta, N.; Di Fonzo, L.M.; Maddaloni, V.; et al. A Child Cohort Study from Southern Italy Enlarges the Genetic Spectrum of Hypertrophic Cardiomyopathy. Clin. Genet. 2009, 76, 91-101. [CrossRef] [PubMed]

104. Otsuka, H.; Arimura, T.; Abe, T.; Kawai, H.; Aizawa, Y.; Kubo, T.; Kitaoka, H.; Nakamura, H.; Nakamura, K.; Okamoto, H.; et al. Prevalence and Distribution of Sarcomeric Gene Mutations in Japanese Patients with Familial Hypertrophic Cardiomyopathy. Circ. J. 2012, 76, 453-461. [CrossRef] [PubMed]

105. Fokstuen, S.; Munoz, A.; Melacini, P.; Iliceto, S.; Perrot, A.; Özcelik, C.; Jeanrenaud, X.; Rieubland, C.; Farr, M.; Faber, L. Rapid Detection of Genetic Variants in Hypertrophic Cardiomyopathy by Custom DNA Resequencing Array in Clinical Practice. J. Med. Genet. 2011, 48, 572-576. [CrossRef]

106. Jongbloed, R.J.; Marcelis, C.L.; Doevendans, P.A.; Schmeitz-Mulkens, J.M.; Van Dockum, W.G.; Geraedts, J.P.; Smeets, H.J. Variable Clinical Manifestation of a Novel Missense Mutation in the Alpha-Tropomyosin (TPM1) Gene in Familial Hypertrophic Cardiomyopathy. J. Am. Coll. Cardiol. 2003, 41, 981-986. [CrossRef]

107. Dorsch, L.M.; Kuster, D.W.D.; Jongbloed, J.D.H.; Boven, L.G.; van Spaendonck-Zwarts, K.Y.; Suurmeijer, A.J.H.; Vink, A.; du Marchie Sarvaas, G.J.; van den Berg, M.P.; van der Velden, J.; et al. The Effect of Tropomyosin Variants on Cardiomyocyte Function and Structure That Underlie Different Clinical Cardiomyopathy Phenotypes. Int. J. Cardiol. 2021, 323, 251-258. [CrossRef]

108. Nakajima-Taniguchi, C.; Matsui, H.; Nagata, S.; Kishimoto, T.; Yamauchi-Takihara, K. Novel Missense Mutation in $\alpha$-Tropomyosin Gene Found in Japanese Patients with Hypertrophic Cardiomyopathy. J. Mol. Cell. Cardiol. 1995, 27, 2053-2058. [CrossRef]

109. Yamauchi-Takihara, K.; Nakajima-Taniguchi, C.; Matsui, H.; Fujio, Y.; Kunisada, K.; Nagata, S.; Kishimoto, T. Clinical Implications of Hypertrophic Cardiomyopathy Associated with Mutations in the Alpha-Tropomyosin Gene. Heart 1996, 76, 63-65. [CrossRef]

110. Karibe, A.; Tobacman, L.S.; Strand, J.; Butters, C.; Back, N.; Bachinski, L.L.; Arai, A.E.; Ortiz, A.; Roberts, R.; Homsher, E.; et al. Hypertrophic Cardiomyopathy Caused by a Novel Alpha-Tropomyosin Mutation (V95A) Is Associated with Mild Cardiac Phenotype, Abnormal Calcium Binding to Troponin, Abnormal Myosin Cycling, and Poor Prognosis. Circulation 2001, 103, 65-71. [CrossRef]

111. Regitz-Zagrosek, V.; Erdmann, J.; Wellnhofer, E.; Raible, J.; Fleck, E. Novel Mutation in the $\alpha$-Tropomyosin Gene and Transition From Hypertrophic to Hypocontractile Dilated Cardiomyopathy. Circulation 2000, 102, e112-e116. [CrossRef]

112. Ebashi, S.; Kodama, A. A New Protein Factor Promoting Aggregation of Tropomyosin. J. Biochem. 1965, 58, 107-108. [CrossRef] [PubMed]

113. Parmacek, M.S.; Solaro, R.J. Biology of the Troponin Complex in Cardiac Myocytes. Prog. Cardiovasc. Dis. 2004, 47, 159-176. [CrossRef]

114. Risi, C.M.; Pepper, I.; Belknap, B.; Landim-Vieira, M.; White, H.D.; Dryden, K.; Pinto, J.R.; Chase, P.B.; Galkin, V.E. The Structure of the Native Cardiac Thin Filament at Systolic Ca ${ }^{2+}$ Levels. Proc. Natl. Acad. Sci. USA 2021, 118, e2024288118. [CrossRef] [PubMed]

115. Rayani, K.; Seffernick, J.T.; Li, Y.A.; Davis, J.P.; Spuches, A.M.; Van Petegem, F.; Solaro, R.J.; Lindert, S.; Tibbits, G.F. Binding of Calcium and Magnesium to Cardiac Troponin C. bioRxiv 2020. [CrossRef]

116. Tadros, H.J.; Life, C.S.; Garcia, G.; Pirozzi, E.; Jones, E.G.; Datta, S.; Parvatiyar, M.S.; Chase, P.B.; Allen, H.D.; Kim, J.J.; et al. Meta-Analysis of Cardiomyopathy-Associated Variants in Troponin Genes Identifies Loci and Intragenic Hot Spots That Are Associated with Worse Clinical Outcomes. J. Mol. Cell. Cardiol. 2020, 142, 118-125. [CrossRef]

117. Reinoso, T.R.; Landim-Vieira, M.; Shi, Y.; Johnston, J.R.; Chase, P.B.; Parvatiyar, M.S.; Landstrom, A.P.; Pinto, J.R.; Tadros, H.J. A Comprehensive Guide to Genetic Variants and Post-Translational Modifications of Cardiac Troponin C. J. Muscle Res. Cell Motil. 2020. [CrossRef]

118. Gillis, T.E.; Marshall, C.R.; Tibbits, G.F. Functional and Evolutionary Relationships of Troponin C. Physiol. Genom. 2007, 32, 16-27. [CrossRef] [PubMed]

119. Li, A.Y.; Stevens, C.M.; Liang, B.; Rayani, K.; Little, S.; Davis, J.; Tibbits, G.F. Familial Hypertrophic Cardiomyopathy Related Cardiac Troponin C L29Q Mutation Alters Length-Dependent Activation and Functional Effects of Phosphomimetic Troponin I. PLoS ONE 2013, 8, e79363. [CrossRef]

120. Schmidtmann, A.; Lindow, C.; Villard, S.; Heuser, A.; Mügge, A.; Gessner, R.; Granier, C.; Jaquet, K. Cardiac Troponin C-L29Q, Related to Hypertrophic Cardiomyopathy, Hinders the Transduction of the Protein Kinase A Dependent Phosphorylation Signal from Cardiac Troponin I to C. FEBS J. 2005, 272, 6087-6097. [CrossRef]

121. Dweck, D.; Hus, N.; Potter, J.D. Challenging Current Paradigms Related to Cardiomyopathies: Are changes in the Ca ${ }^{2+}$ sensitivity of myofilaments containing cardiac Troponin C mutations (G159D and L29Q) good predictors of the phenotypic outcomes? J. Biol. Chem. 2008, 283, 33119-33128. [CrossRef]

122. Landstrom, A.P.; Parvatiyar, M.S.; Pinto, J.R.; Marquardt, M.L.; Bos, J.M.; Tester, D.J.; Ommen, S.R.; Potter, J.D.; Ackerman, M.J. Molecular and Functional Characterization of Novel Hypertrophic Cardiomyopathy Susceptibility Mutations in TNNC1-Encoded Troponin C. J. Mol. Cell. Cardiol. 2008, 45, 281-288. [CrossRef] [PubMed]

123. Kawai, M.; Johnston, J.R.; Karam, T.; Wang, L.; Singh, R.K.; Pinto, J.R. Myosin Rod Hypophosphorylation and CB Kinetics in Papillary Muscles from a TnC-A8V KI Mouse Model. Biophys. J. 2017, 112, 1726-1736. [CrossRef] 
124. Parvatiyar, M.S.; Landstrom, A.P.; Figueiredo-Freitas, C.; Potter, J.D.; Ackerman, M.J.; Pinto, J.R. A Mutation in TNNC1-encoded Cardiac Troponin C, TNNC1-A31S, Predisposes to Hypertrophic Cardiomyopathy and Ventricular Fibrillation. J. Biol. Chem. 2012, 287, 31845-31855. [CrossRef] [PubMed]

125. Zot, H.G.; Hasbun, J.E.; Michell, C.A.; Landim-Vieira, M.; Pinto, J.R. Enhanced Troponin I Binding Explains the Functional Changes Produced by the Hypertrophic Cardiomyopathy Mutation A8V of Cardiac Troponin C. Arch. Biochem. Biophys. 2016, 601, 97-104. [CrossRef]

126. Hassoun, R.; Budde, H.; Mannherz, H.G.; Lódi, M.; Fujita-Becker, S.; Laser, K.T.; Gärtner, A.; Klingel, K.; Möhner, D.; Stehle, R.; et al. De Novo Missense Mutations in TNNC1 and TNNI3 Causing Severe Infantile Cardiomyopathy Affect Myofilament Structure and Function and Are Modulated by Troponin Targeting Agents. Int. J. Mol. Sci. 2021, 22, 9625. [CrossRef]

127. Potter, J.D.; Sheng, Z.; Pan, B.S.; Zhao, J. A Direct Regulatory Role for Troponin T and a Dual Role for Troponin C in the Ca ${ }^{2+}$ Regulation of Muscle Contraction. J. Biol. Chem. 1995, 270, 2557-2562. [CrossRef]

128. Swindle, N.; Tikunova, S.B. Hypertrophic Cardiomyopathy-Linked Mutation D145E Drastically Alters Calcium Binding by the C-Domain of Cardiac Troponin C. Biochemistry 2010, 49, 4813-4820. [CrossRef]

129. Marques, M.D.; Pinto, J.R.; Moraes, A.H.; Iqbal, A.; de Magalhães, M.T.Q.; Monteiro, J.; Pedrote, M.M.; Sorenson, M.M.; Silva, J.L.; de Oliveira, G.A.P. Allosteric Transmission along a Loosely Structured Backbone Allows a Cardiac Troponin C Mutant to Function with Only One $\mathrm{Ca}^{2+}$ Ion. J. Biol. Chem. 2017, 292, 2379-2394. [CrossRef] [PubMed]

130. Ploski, R.; Rydzanicz, M.; Ksiazczyk, T.M.; Franaszczyk, M.; Pollak, A.; Kosinska, J.; Michalak, E.; Stawinski, P.; Ziolkowska, L.; Bilinska, Z.T.; et al. Evidence for Troponin C (TNNC1) as a Gene for Autosomal Recessive Restrictive Cardiomyopathy with Fatal Outcome in Infancy. Am. J. Med. Genet. Part A 2016, 170, 3241-3248. [CrossRef]

131. Vasilescu, C.; Ojala, T.H.; Brilhante, V.; Ojanen, S.; Hinterding, H.M.; Palin, E.; Alastalo, T.-P.; Koskenvuo, J.; Hiippala, A.; Jokinen, E.; et al. Genetic Basis of Severe Childhood-Onset Cardiomyopathies. J. Am. Coll. Cardiol. 2018, 72, 2324-2338. [CrossRef]

132. Mogensen, J.; Murphy, R.T.; Shaw, T.; Bahl, A.; Redwood, C.; Watkins, H.; Burke, M.; Elliott, P.M.; McKenna, W.J. Severe Disease Expression of Cardiac Troponin C and T Mutations in Patients with Idiopathic Dilated Cardiomyopathy. J. Am. Coll. Cardiol. 2004, 44, 2033-2040. [CrossRef] [PubMed]

133. Biesiadecki, B.J.; Kobayashi, T.; Walker, J.S.; John Solaro, R.; de Tombe, P.P. The Troponin C G159D Mutation Blunts Myofilament Desensitization Induced by Troponin I Ser23/24 Phosphorylation. Circ. Res. 2007, 100, 1486-1493. [CrossRef] [PubMed]

134. Li, M.X.; Hwang, P.M. Structure and Function of Cardiac Troponin C (TNNC1): Implications for Heart Failure, Cardiomyopathies, and Troponin Modulating Drugs. Gene 2015, 571, 153-166. [CrossRef] [PubMed]

135. Lim, C.C.; Yang, H.; Yang, M.; Wang, C.-K.; Shi, J.; Berg, E.A.; Pimentel, D.R.; Gwathmey, J.K.; Hajjar, R.J.; Helmes, M.; et al. A Novel Mutant Cardiac Troponin C Disrupts Molecular Motions Critical for Calcium Binding Affinity and Cardiomyocyte Contractility. Biophys. J. 2008, 94, 3577-3589. [CrossRef] [PubMed]

136. Dweck, D.; Reynaldo, D.P.; Pinto, J.R.; Potter, J.D. A Dilated Cardiomyopathy Troponin C Mutation Lowers Contractile Force by Reducing Strong Myosin-Actin Binding. J. Biol. Chem. 2010, 285, 17371-17379. [CrossRef]

137. Landim-Vieira, M.; Johnston, J.R.; Ji, W.; Mis, E.K.; Tijerino, J.; Spencer-Manzon, M.; Jeffries, L.; Hall, E.K.; Panisello-Manterola, D.; Khokha, M.K.; et al. Familial Dilated Cardiomyopathy Associated With a Novel Combination of Compound Heterozygous TNNC1 Variants. Front. Physiol. 2019, 10, 1612. [CrossRef] [PubMed]

138. Layland, J.; Solaro, R.J.; Shah, A.M. Regulation of Cardiac Contractile Function by Troponin I Phosphorylation. Cardiovasc. Res. 2005, 66, 12-21. [CrossRef]

139. Lu, Q.-W.; Wu, X.-Y.; Morimoto, S. Inherited Cardiomyopathies Caused by Troponin Mutations. J. Geriatr. Cardiol. 2013, 10, 91-101. [CrossRef]

140. Mogensen, J.; Kubo, T.; Duque, M.; Uribe, W.; Shaw, A.; Murphy, R.; Gimeno, J.R.; Elliott, P.; McKenna, W.J. Idiopathic Restrictive Cardiomyopathy Is Part of the Clinical Expression of Cardiac Troponin I Mutations. J. Clin. Investig. 2003, 111, 209-216. [CrossRef]

141. Kobayashi, T.; Solaro, R.J. Increased $\mathrm{Ca}^{2+}$ Affinity of Cardiac Thin Filaments Reconstituted with Cardiomyopathy-Related Mutant Cardiac Troponin I. J. Biol. Chem. 2006, 281, 13471-13477. [CrossRef]

142. Liu, X.; Zhang, L.; Pacciulli, D.; Zhao, J.; Nan, C.; Shen, W.; Quan, J.; Tian, J.; Huang, X. Restrictive Cardiomyopathy Caused by Troponin Mutations: Application of Disease Animal Models in Translational Studies. Front. Physiol. 2016, 7, 629. [CrossRef]

143. Willott, R.H.; Gomes, A.V.; Chang, A.N.; Parvatiyar, M.S.; Pinto, J.R.; Potter, J.D. Mutations in Troponin That Cause HCM, DCM AND RCM: What Can We Learn about Thin Filament Function? J. Mol. Cell. Cardiol. 2010, 48, 882-892. [CrossRef] [PubMed]

144. Deng, Y.; Schmidtmann, A.; Kruse, S.; Filatov, V.; Heilmeyer, L.M.G.; Jaquet, K.; Thieleczek, R. Phosphorylation of Human Cardiac Troponin I G203S and K206Q Linked to Familial Hypertrophic Cardiomyopathy Affects Actomyosin Interaction in Different Ways. J. Mol. Cell. Cardiol. 2003, 35, 1365-1374. [CrossRef] [PubMed]

145. Carballo, S.; Robinson, P.; Otway, R.; Fatkin, D.; Jongbloed, J.D.H.; de Jonge, N.; Blair, E.; van Tintelen, J.P.; Redwood, C.; Watkins, H. Identification and Functional Characterization of Cardiac Troponin I As a Novel Disease Gene in Autosomal Dominant Dilated Cardiomyopathy. Circ. Res. 2009, 105, 375-382. [CrossRef] [PubMed]

146. Gomes, A.V.; Guzman, G.; Zhao, J.; Potter, J.D. Cardiac Troponin T Isoforms Affect the Ca2+Sensitivity and Inhibition of Force Development: Insights into the role of Troponin T isoforms in the heart. J. Biol. Chem. 2002, 277, 35341-35349. [CrossRef] [PubMed]

147. Sumandea, M.P.; Pyle, W.G.; Kobayashi, T.; de Tombe, P.P.; Solaro, R.J. Identification of a Functionally Critical Protein Kinase C Phosphorylation Residue of Cardiac Troponin T. J. Biol. Chem. 2003, 278, 35135-35144. [CrossRef] [PubMed] 
148. Wei, B.; Jin, J.-P. TNNT1, TNNT2, and TNNT3: Isoform Genes, Regulation, and Structure-Function Relationships. Gene 2016, 582, 1-13. [CrossRef]

149. Manning, E.P.; Tardiff, J.C.; Schwartz, S.D. Molecular Effects of Familial Hypertrophic Cardiomyopathy-Related Mutations in the TNT1 Domain of CTnT. J. Mol. Biol. 2012, 421, 54-66. [CrossRef] [PubMed]

150. Pinto, J.R.; Parvatiyar, M.S.; Jones, M.A.; Liang, J.; Potter, J.D. A Troponin T Mutation That Causes Infantile Restrictive Cardiomyopathy Increases $\mathrm{Ca}^{2+}$ Sensitivity of Force Development and Impairs the Inhibitory Properties of Troponin. J. Biol. Chem. 2008, 283, 2156-2166. [CrossRef]

151. Wu, H.; Yang, H.; Rhee, J.-W.; Zhang, J.Z.; Lam, C.K.; Sallam, K.; Chang, A.C.Y.; Ma, N.; Lee, J.; Zhang, H.; et al. Modelling Diastolic Dysfunction in Induced Pluripotent Stem Cell-Derived Cardiomyocytes from Hypertrophic Cardiomyopathy Patients. Eur. Heart J. 2019, 40, 3685-3695. [CrossRef]

152. Gomes, A.V.; Potter, J.D. Molecular and Cellular Aspects of Troponin Cardiomyopathies. Ann. N. Y. Acad. Sci. 2004, 1015, 214-224. [CrossRef]

153. Gomes, A.V.; Liang, J.; Potter, J.D. Mutations in Human Cardiac Troponin I That Are Associated with Restrictive Cardiomyopathy Affect Basal ATPase Activity and the Calcium Sensitivity of Force Development. J. Biol. Chem. 2005, 280, 30909-30915. [CrossRef]

154. Palmiter, K.A.; Tyska, M.J.; Haeberle, J.R.; Alpert, N.R.; Fananapazir, L.; Warshaw, D.M. R403Q and L908V Mutant Beta-Cardiac Myosin from Patients with Familial Hypertrophic Cardiomyopathy Exhibit Enhanced Mechanical Performance at the Single Molecule Level. J. Muscle Res. Cell Motil. 2000, 21, 609-620. [CrossRef]

155. Szczesna-Cordary, D.; Guzman, G.; Zhao, J.; Hernandez, O.; Wei, J.; Diaz-Perez, Z. The E22K Mutation of Myosin RLC That Causes Familial Hypertrophic Cardiomyopathy Increases Calcium Sensitivity of Force and ATPase in Transgenic Mice. J. Cell Sci. 2005, 118, 3675-3683. [CrossRef]

156. Toepfer, C.N.; Wakimoto, H.; Garfinkel, A.C.; McDonough, B.; Liao, D.; Jiang, J.; Tai, A.C.; Gorham, J.M.; Lunde, I.G.; Lun, M.; et al. Hypertrophic Cardiomyopathy Mutations in MYBPC3 Dysregulate Myosin. Sci. Transl. Med. 2019, 11, 476. [CrossRef]

157. Yang, Q.; Sanbe, A.; Osinska, H.; Hewett, T.E.; Klevitsky, R.; Robbins, J. A Mouse Model of Myosin Binding Protein C Human Familial Hypertrophic Cardiomyopathy. J. Clin. Investig. 1998, 102, 1292-1300. [CrossRef] [PubMed]

158. Shchepkin, D.V.; Matyushenko, A.M.; Kopylova, G.V.; Artemova, N.V.; Bershitsky, S.Y.; Tsaturyan, A.K.; Levitsky, D.I. Stabilization of the Central Part of Tropomyosin Molecule Alters the Ca2+-Sensitivity of Actin-Myosin Interaction. Acta Nat. 2013, 5, 126-129. [CrossRef]

159. Hamdani, N.; Kooij, V.; van Dijk, S.; Merkus, D.; Paulus, W.J.; dos Remedios, C.; Duncker, D.J.; Stienen, G.J.M.; van der Velden, J. Sarcomeric Dysfunction in Heart Failure. Cardiovasc. Res. 2008, 77, 649-658. [CrossRef]

160. van der Velden, J.; Papp, Z.; Zaremba, R.; Boontje, N.M.; de Jong, J.W.; Owen, V.J.; Burton, P.B.J.; Goldmann, P.; Jaquet, K.; Stienen, G.J.M. Increased $\mathrm{Ca}^{2+}$-Sensitivity of the Contractile Apparatus in End-Stage Human Heart Failure Results from Altered Phosphorylation of Contractile Proteins. Cardiovasc. Res. 2003, 57, 37-47. [CrossRef]

161. Hoskins, A.C.; Jacques, A.; Bardswell, S.C.; McKenna, W.J.; Tsang, V.; dos Remedios, C.G.; Ehler, E.; Adams, K.; Jalilzadeh, S.; Avkiran, M.; et al. Normal Passive Viscoelasticity but Abnormal Myofibrillar Force Generation in Human Hypertrophic Cardiomyopathy. J. Mol. Cell. Cardiol. 2010, 49, 737-745. [CrossRef] [PubMed]

162. Cuello, F.; Bardswell, S.C.; Haworth, R.S.; Yin, X.; Lutz, S.; Wieland, T.; Mayr, M.; Kentish, J.C.; Avkiran, M. Protein Kinase D Selectively Targets Cardiac Troponin I and Regulates Myofilament $\mathrm{Ca}^{2+}$ Sensitivity in Ventricular Myocytes. Circ. Res. 2007, 100, 864-873. [CrossRef]

163. Dvornikov, A.V.; Smolin, N.; Zhang, M.; Martin, J.L.; Robia, S.L.; de Tombe, P.P. Restrictive Cardiomyopathy Troponin I R145W Mutation Does Not Perturb Myofilament Length-Dependent Activation in Human Cardiac Sarcomeres. J. Biol. Chem. 2016, 291, 21817-21828. [CrossRef]

164. Cheng, Y.; Rao, V.; Tu, A.; Lindert, S.; Wang, D.; Oxenford, L.; McCulloch, A.D.; McCammon, J.A.; Regnier, M. Troponin I Mutations R146G and R21C Alter Cardiac Troponin Function, Contractile Properties, and Modulation by Protein Kinase A (PKA)-Mediated Phosphorylation. J. Biol. Chem. 2015, 290, 27749-27766. [CrossRef]

165. Lindert, S.; Cheng, Y.; Kekenes-Huskey, P.; Regnier, M.; McCammon, J.A. Effects of HCM CTnI Mutation R145G on Troponin Structure and Modulation by PKA Phosphorylation Elucidated by Molecular Dynamics Simulations. Biophys. J. 2015, 108, 395-407. [CrossRef]

166. Sequeira, V.; Wijnker, P.J.M.; Nijenkamp, L.L.A.M.; Kuster, D.W.D.; Najafi, A.; Witjas-Paalberends, E.R.; Regan, J.A.; Boontje, N.; Ten Cate, F.J.; Germans, T.; et al. Perturbed Length-Dependent Activation in Human Hypertrophic Cardiomyopathy with Missense Sarcomeric Gene Mutations. Circ. Res. 2013, 112, 1491-1505. [CrossRef]

167. De Tombe, P.P.; Mateja, R.D.; Tachampa, K.; Mou, Y.A.; Farman, G.P.; Irving, T.C. Myofilament Length Dependent Activation. J. Mol. Cell. Cardiol. 2010, 48, 851-858. [CrossRef]

168. Wang, X.; Li, M.X.; Spyracopoulos, L.; Beier, N.; Chandra, M.; Solaro, R.J.; Sykes, B.D. Structure of the C-Domain of Human Cardiac Troponin C in Complex with the $\mathrm{Ca}^{2+}$ Sensitizing Drug EMD 57033. J. Biol. Chem. 2001, 276, 25456-25466. [CrossRef]

169. Schober, T.; Huke, S.; Venkataraman, R.; Gryshchenko, O.; Kryshtal, D.; Hwang, H.S.; Baudenbacher, F.J.; Knollmann, B.C. Myofilament Ca Sensitization Increases Cytosolic Ca Binding Affinity, Alters Intracellular Ca Homeostasis, and Causes PauseDependent Ca-Triggered Arrhythmia. Circ. Res. 2012, 111, 170-179. [CrossRef]

170. Parvatiyar, M.S.; Pinto, J.R.; Dweck, D.; Potter, J.D. Cardiac Troponin Mutations and Restrictive Cardiomyopathy. J. Biomed. Biotechnol. 2010, 2010, 350706. [CrossRef] 
171. Witjas-Paalberends, E.R.; Güçlü, A.; Germans, T.; Knaapen, P.; Harms, H.J.; Vermeer, A.M.C.; Christiaans, I.; Wilde, A.A.M.; Dos Remedios, C.; Lammertsma, A.A.; et al. Gene-Specific Increase in the Energetic Cost of Contraction in Hypertrophic Cardiomyopathy Caused by Thick Filament Mutations. Cardiovasc. Res. 2014, 103, 248-257. [CrossRef]

172. Witjas-Paalberends, E.R.; Ferrara, C.; Scellini, B.; Piroddi, N.; Montag, J.; Tesi, C.; Stienen, G.J.M.; Michels, M.; Ho, C.Y.; Kraft, T.; et al. Faster Cross-Bridge Detachment and Increased Tension Cost in Human Hypertrophic Cardiomyopathy with the R403Q MYH7 Mutation. J. Physiol. 2014, 592, 3257-3272. [CrossRef]

173. Davis, J.; Davis, L.C.; Correll, R.N.; Makarewich, C.A.; Schwanekamp, J.A.; Moussavi-Harami, F.; Wang, D.; York, A.J.; Wu, H.; Houser, S.R.; et al. A Tension-Based Model Distinguishes Hypertrophic versus Dilated Cardiomyopathy. Cell 2016, 165, 1147-1159. [CrossRef]

174. Ashrafian, H.; Redwood, C.; Blair, E.; Watkins, H. Hypertrophic Cardiomyopathy:A Paradigm for Myocardial Energy Depletion. Trends Genet. 2003, 19, 263-268. [CrossRef]

175. Varnava, A.M.; Elliott, P.M.; Sharma, S.; McKenna, W.J.; Davies, M.J. Hypertrophic Cardiomyopathy: The Interrelation of Disarray, Fibrosis, and Small Vessel Disease. Heart 2000, 84, 476-482. [CrossRef]

176. Linke, W.A. Sense and Stretchability: The Role of Titin and Titin-Associated Proteins in Myocardial Stress-Sensing and Mechanical Dysfunction. Cardiovasc. Res. 2008, 77, 637-648. [CrossRef]

177. Herwig, M.; Kolijn, D.; Lódi, M.; Hölper, S.; Kovács, Á.; Papp, Z.; Jaquet, K.; Haldenwang, P.; Dos Remedios, C.; Reusch, P.H.; et al. Modulation of Titin-Based Stiffness in Hypertrophic Cardiomyopathy via Protein Kinase D. Front. Physiol. 2020, 11, 240. [CrossRef]

178. Nagueh, S.F.; Shah, G.; Wu, Y.; Torre-Amione, G.; King, N.M.P.; Lahmers, S.; Witt, C.C.; Becker, K.; Labeit, S.; Granzier, H.L. Altered Titin Expression, Myocardial Stiffness, and Left Ventricular Function in Patients with Dilated Cardiomyopathy. Circulation 2004, 110, 155-162. [CrossRef]

179. Neagoe, C.; Kulke, M.; del Monte, F.; Gwathmey, J.K.; de Tombe, P.P.; Hajjar, R.J.; Linke, W.A. Titin Isoform Switch in Ischemic Human Heart Disease. Circulation 2002, 106, 1333-1341. [CrossRef]

180. Makarenko, I.; Opitz, C.A.; Leake, M.C.; Neagoe, C.; Kulke, M.; Gwathmey, J.K.; del Monte, F.; Hajjar, R.J.; Linke, W.A. Passive Stiffness Changes Caused by Upregulation of Compliant Titin Isoforms in Human Dilated Cardiomyopathy Hearts. Circ. Res. 2004, 95, 708-716. [CrossRef]

181. Borbély, A.; Falcao-Pires, I.; van Heerebeek, L.; Hamdani, N.; Edes, I.; Gavina, C.; Leite-Moreira, A.F.; Bronzwaer, J.G.F.; Papp, Z.; van der Velden, J.; et al. Hypophosphorylation of the Stiff N2B Titin Isoform Raises Cardiomyocyte Resting Tension in Failing Human Myocardium. Circ. Res. 2009, 104, 780-786. [CrossRef]

182. Warren, C.M.; Jordan, M.C.; Roos, K.P.; Krzesinski, P.R.; Greaser, M.L. Titin Isoform Expression in Normal and Hypertensive Myocardium. Cardiovasc. Res. 2003, 59, 86-94. [CrossRef]

183. Wu, Y.; Bell, S.P.; Trombitas, K.; Witt, C.C.; Labeit, S.; LeWinter, M.M.; Granzier, H. Changes in Titin Isoform Expression in Pacing-Induced Cardiac Failure Give Rise to Increased Passive Muscle Stiffness. Circulation 2002, 106, 1384-1389. [CrossRef]

184. Koser, F.; Loescher, C.; Linke, W.A. Posttranslational Modifications of Titin from Cardiac Muscle: How, Where, and What For? FEBS J. 2019, 286, 2240-2260. [CrossRef]

185. Kötter, S.; Gout, L.; Von Frieling-Salewsky, M.; Müller, A.E.; Helling, S.; Marcus, K.; Dos Remedios, C.; Linke, W.A.; Krüger, M. Differential Changes in Titin Domain Phosphorylation Increase Myofilament Stiffness in Failing Human Hearts. Cardiovasc. Res. 2013, 99, 648-656. [CrossRef]

186. Krüger, M.; Kötter, S.; Grützner, A.; Lang, P.; Andresen, C.; Redfield, M.M.; Butt, E.; Dos Remedios, C.G.; Linke, W.A. Protein Kinase G Modulates Human Myocardial Passive Stiffness by Phosphorylation of the Titin Springs. Circ. Res. 2009, 104, 87-94. [CrossRef] [PubMed]

187. Green, E.M.; Wakimoto, H.; Anderson, R.L.; Evanchik, M.J.; Gorham, J.M.; Harrison, B.C.; Henze, M.; Kawas, R.; Oslob, J.D.; Rodriguez, H.M.; et al. A Small-Molecule Inhibitor of Sarcomere Contractility Suppresses Hypertrophic Cardiomyopathy in Mice. Science 2016, 351, 617-621. [CrossRef] [PubMed]

188. Baudenbacher, F.; Schober, T.; Pinto, J.R.; Sidorov, V.Y.; Hilliard, F.; Solaro, R.J.; Potter, J.D.; Knollmann, B.C. Myofilament Ca ${ }^{2+}$ Sensitization Causes Susceptibility to Cardiac Arrhythmia in Mice. J. Clin. Investig. 2008, 118, 3893-3903. [CrossRef]

189. Dou, Y.; Arlock, P.; Arner, A. Blebbistatin Specifically Inhibits Actin-Myosin Interaction in Mouse Cardiac Muscle. Am. J. Physiol. Physiol. 2007, 293, C1148-C1153. [CrossRef] [PubMed]

190. Cleland, J.G.F.; Teerlink, J.R.; Senior, R.; Nifontov, E.M.; Mc Murray, J.J.V.; Lang, C.C.; Tsyrlin, V.A.; Greenberg, B.H.; Mayet, J.; Francis, D.P.; et al. The Effects of the Cardiac Myosin Activator, Omecamtiv Mecarbil, on Cardiac Function in Systolic Heart Failure: A Double-Blind, Placebo-Controlled, Crossover, Dose-Ranging Phase 2 Trial. Lancet 2011, 378, 676-683. [CrossRef]

191. Kampourakis, T.; Zhang, X.; Sun, Y.-B.; Irving, M. Omecamtiv Mercabil and Blebbistatin Modulate Cardiac Contractility by Perturbing the Regulatory State of the Myosin Filament. J. Physiol. 2018, 596, 31-46. [CrossRef]

192. Sorsa, T.; Pollesello, P.; Solaro, R.J. The Contractile Apparatus as a Target for Drugs against Heart Failure: Interaction of Levosimendan, a Calcium Sensitiser, with Cardiac Troponin C. Mol. Cell. Biochem. 2004, 266, 87-107. [CrossRef] [PubMed]

193. Papp, Z.; Édes, I.; Fruhwald, S.; De Hert, S.G.; Salmenperä, M.; Leppikangas, H.; Mebazaa, A.; Landoni, G.; Grossini, E.; Caimmi, P.; et al. Levosimendan: Molecular Mechanisms and Clinical Implications: Consensus of Experts on the Mechanisms of Action of Levosimendan. Int. J. Cardiol. 2012, 159, 82-87. [CrossRef] [PubMed]

194. Robertson, I.M.; Li, M.X.; Sykes, B.D. Solution Structure of Human Cardiac Troponin C in Complex with the Green Tea Polyphenol, (-)-Epigallocatechin 3-Gallate. J. Biol. Chem. 2009, 284, 23012-23023. [CrossRef] [PubMed] 
195. Tadano, N.; Du, C.; Yumoto, F.; Morimoto, S.; Ohta, M.; Xie, M.; Nagata, K.; Zhan, D.; Lu, Q.; Miwa, Y. Biological Actions of Green Tea Catechins on Cardiac Troponin C. Br. J. Pharmacol. 2010, 161, 1034-1043. [CrossRef] [PubMed]

196. Alsulami, K.; Marston, S. Small Molecules Acting on Myofilaments as Treatments for Heart and Skeletal Muscle Diseases. Int. J. Mol. Sci. 2020, 21, 9599. [CrossRef]

197. Prondzynski, M.; Krämer, E.; Laufer, S.D.; Shibamiya, A.; Pless, O.; Flenner, F.; Müller, O.J.; Münch, J.; Redwood, C.; Hansen, A.; et al. Evaluation of MYBPC3 Trans-Splicing and Gene Replacement as Therapeutic Options in Human IPSC-Derived Cardiomyocytes. Mol. Ther.-Nucleic Acids 2017, 7, 475-486. [CrossRef]

198. Jiang, J.; Wakimoto, H.; Seidman, J.G.; Seidman, C.E. Allele-Specific Silencing of Mutant Myh6 Transcripts in Mice Suppresses Hypertrophic Cardiomyopathy. Science 2013, 342, 111-114. [CrossRef]

199. Ma, H.; Marti-Gutierrez, N.; Park, S.-W.; Wu, J.; Lee, Y.; Suzuki, K.; Koski, A.; Ji, D.; Hayama, T.; Ahmed, R.; et al. Correction of a Pathogenic Gene Mutation in Human Embryos. Nature 2017, 548, 413-419. [CrossRef] 